IZA DP No. 9302

Do Boys and Girls Use Computers Differently, and Does It Contribute to Why Boys Do Worse in School than Girls?

Robert W. Fairlie

August 2015 


\title{
Do Boys and Girls Use Computers Differently, and Does It Contribute to Why Boys Do Worse in School than Girls?
}

\author{
Robert W. Fairlie \\ University of California, Santa Cruz \\ and IZA \\ Discussion Paper No. 9302 \\ August 2015
}

IZA

P.O. Box 7240

53072 Bonn

Germany

Phone: +49-228-3894-0

Fax: +49-228-3894-180

E-mail: iza@iza.org

Any opinions expressed here are those of the author(s) and not those of IZA. Research published in this series may include views on policy, but the institute itself takes no institutional policy positions. The IZA research network is committed to the IZA Guiding Principles of Research Integrity.

The Institute for the Study of Labor (IZA) in Bonn is a local and virtual international research center and a place of communication between science, politics and business. IZA is an independent nonprofit organization supported by Deutsche Post Foundation. The center is associated with the University of Bonn and offers a stimulating research environment through its international network, workshops and conferences, data service, project support, research visits and doctoral program. IZA engages in (i) original and internationally competitive research in all fields of labor economics, (ii) development of policy concepts, and (iii) dissemination of research results and concepts to the interested public.

IZA Discussion Papers often represent preliminary work and are circulated to encourage discussion. Citation of such a paper should account for its provisional character. A revised version may be available directly from the author. 


\section{ABSTRACT \\ Do Boys and Girls Use Computers Differently, and Does It Contribute to Why Boys Do Worse in School than Girls?*}

Boys are doing worse in school than are girls, which has been dubbed "the Boy Crisis". An analysis of the latest data on educational outcomes among boys and girls reveals extensive disparities in grades, reading and writing test scores, and other measurable educational outcomes, and these disparities exist across family resources and race. Focusing on disadvantaged schoolchildren, I then examine whether time investments made by boys and girls related to computer use contribute to the gender gap in academic achievement. Data from several sources indicate that boys are less likely to use computers for schoolwork and are more likely to use computers for playing games, but are less likely to use computers for social networking and email than are girls. Using data from a large field experiment randomly providing free personal computers to schoolchildren for home use, I also test whether these differential patterns of computer use displace homework time and ultimately translate into worse educational outcomes among boys. No evidence is found indicating that personal computers crowd out homework time and effort for disadvantaged boys relative to girls. Home computers also do not have negative effects on educational outcomes such as grades, test scores, courses completed, and tardies for disadvantaged boys relative to girls.

JEL Classification: $\quad$ C93, I24, J16

Keywords: technology, computers, ICT, education, gender, field experiment, poverty

Corresponding author:

Robert W. Fairlie

Department of Economics

University of California, Santa Cruz

Santa Cruz, CA 95064

USA

E-mail:rfairlie@ucsc.edu

\footnotetext{
* I would like to thank Computers for Classrooms, Inc., the ZeroDivide Foundation, and the NET Institute for generous funding for the project. I would also like to thank seminar participants at Stanford University, University of Toronto, Santa Clara University, Wellesley College, the Chicano Latino Research Center at UC Santa Cruz, and Claremont McKenna College for comments and suggestions. I would also like to thank Jennifer Bevers, Bruce Besnard John Bohannon, Linda Coleman, Reg Govan, Rebecka Hagerty, Kathleen Hannah-Chambas, Brian Gault, David Jansen, Cynthia Kampf, Gina Lanphier, Linda Leonard, Kurt Madden, Lee McPeak, Stephen Morris, Joanne Parsley, Richard Pascual, Jeanette Sanchez, Zenae Scott, Tom Sharp, and many others for administering the program in schools. Shilpa Aggarwal, Julian Caballero, David Castaneda, James Chiu, Samantha Grunberg, Brandon Heck, Keith Henwood, Cody Kennedy, Nicole Mendoza, Nick Parker, Miranda Schirmer, Eva Shapiro, Glen Wolf and Heidi Wu are also thanked for research assistance. Finally, special thanks go to Pat Furr for donating many computers for the study and distributing computers to schools.
} 


\section{Do Boys and Girls Use Computers Differently, and Does It Contribute to Why Boys do Worse in School than Girls?}

\section{Introduction}

Boys do worse in school than girls. They obtain lower grades, and are less likely to graduate from high school and attend college (NCES 2012). ${ }^{1}$ These gender disparities in academic performance exist for minority and low-income schoolchildren as well as for more advantaged schoolchildren. One factor that might contribute to why boys and girls differ in academic performance is that they make different time investments after school. ${ }^{2}$ For example, boys might spend more time playing video games, "playing around" on computers, watching TV, and using other forms of media than girls. All of these activities might crowd out time spent doing homework and studying for exams. A recent national time-use diary survey found that children consume $7 \frac{1}{2}$ hours of media a day and this level of use is 20 percent higher than it was only five years ago (Kaiser Family Foundation 2010). The average length of a school day in the United States is roughly 6 1/2 hours (NCES 2012). These time investments made at young ages between educational and non-educational activities might have long lasting effects on educational attainment. Surprisingly, very little research has focused on the time investments made by children and their consequences for educational outcomes.

\footnotetext{
${ }^{1}$ The media has dubbed these disparities as the "Boy Crisis." See "The Boy Crisis. At Every Level of Education, They're Falling Behind. What to Do?" Newsweek (Jan. 30, 2006), "Raising Cain: Boys in Focus," PBS (Jan. 12, 2006), "The Boys Have Fallen Behind," NY Times (March 27, 2010), and "The Boys at the Back," NY Times (February 2, 2013) for example.

${ }^{2}$ The reversal of the gender gap in college education with women now earning more college degrees than men has been well documented (see Sundstrom 2004; Goldin, Katz, and Kuziemko 2006 for example), but disparities between boys and girls in academic performance have drawn much less research attention. The underlying causes of these disparities are not well known. Some of the potential explanations examined in recent studies include a disproportionate representation of female teachers in younger grades, girls are more self-disciplined, girls respond more to pre-school interventions, girls are more ready to learn, differential treatment by teachers, and larger positive impacts for girls by Teach for America teachers (Dee 2007; Duckworth and Seligman 2006; Anderson 2008; Cornwell, Mustard and Van Parys 2013; Malamud and Schanzenbach 2007; Antecol, Eren and Ozbeklik 2013).
} 
Of particular concern are the potential consequences of computer use among boys and girls. Computer use is one of the largest types of media use among children (Kaiser Family Foundation 2010), and thus extensive use of computers after school for video games, social networking and other entertainment activities might crowd out homework and study time among schoolchildren. There is evidence in the previous literature of computer use crowding out schoolwork and negative effects on academic performance. For example, Malumed and PopEleches (2011) find evidence of heavy game use of computers and negative effects of computers on reading, homework and grades, and Fuchs and Woessmann (2004) find a negative relationship between home computers and math and reading test scores, possibly due to the distracting effects of children "playing computer games." ${ }^{33}$ If boys have higher levels of access to home computers, use computers more for playing games, or use computers less for schoolwork than girls, computers may partly contribute to why boys do worse in school. A better understanding of these potential effects is especially important for low-income and minority schoolchildren because of the policy focus on expanding access to technology to reduce the digital divide. $^{4}$

In this paper, I first examine the latest national data on academic performance among girls and boys focusing on disadvantaged schoolchildren. I then explore three hypotheses

\footnotetext{
${ }^{3}$ Concerns over the negative effects of home computers have gained a fair amount of attention recently in the press. See, for example, "Computers at Home: Educational Hope vs. Teenage Reality," NY Times, July 10, 2010 and "Wasting Time Is New Divide in Digital Era," NY Times, May 29, 2012. Extensive use of social networking sites, such as Facebook, is one particular concern (e.g., see Karpinski 2009; Pasek and Hargittai 2009). These concerns are similar to those over television (e.g., see Zavodny 2006).

${ }^{4}$ The U.S. federal government spends more than $\$ 2$ billion per year on the E-rate program, which provides discounts to schools and libraries for the costs of telecommunications services and equipment (Puma, et al. 2000, Universal Services Administration Company 2013). England provided free computers to nearly 300,000 low-income families with children at a total cost of £194 million through the Home Access Programme. Additional policies include tax breaks, special loans and Individual Development Accounts (IDA) for educational purchases of computers, community technology centers, and laptop checkout programs for students (Servon 2002, Lazarus 2006, and Gordo 2008).
} 
regarding computer use and these differences. First, I examine whether girls and boys have differential access rates to personal computers at home. Using microdata from the Computer and Internet Supplement to the Current Population Survey (CPS), I examine whether computer access rates vary across boy-only, girl-only and boy-girl families, and whether there are gender differences for low-income and minority schoolchildren. Second, I explore whether disadvantaged boys and girls use computers differently. Are boys more likely to use computers for video games and other non-educational activities, and are they less likely to use computers for schoolwork? Although a few previous studies examine gender differences in computer and Internet use among adults, very little is known about gender differences in the use of computers among children. ${ }^{5}$ Using data from three sources, I conduct the first detailed examination of computer and Internet use among boys and girls. Computer use for game playing, social networking, schoolwork and other activities is examined.

Third, I explore whether boy-girl differences in computer use crowd out homework time and effort differently, and contribute to gender disparities in educational outcomes among disadvantaged schoolchildren. To test this hypothesis I estimate the effects of home computers on homework time and effort, grades, standardized test scores, and several additional educational outcomes for girls and boys. Given similar access rates, if home computers have a larger negative impact on educational outcomes for boys than for girls then differential computer use at home widens the achievement gap. If instead, home computers have a similar effect for boys and girls then differential computer use does not contribute to the achievement gap. To remove

\footnotetext{
${ }^{5}$ Men and women are found to have very similar levels of access to computers and the Internet, but differ in intensity of use and activities, and possibly benefits (see Ono and Zavodny 2003; Hargittai 2007; Mossberger 2008; NTIA 2011; Figlio, et al. 2012 for example). Differences in access and use, however, are substantially larger by race and income (see Hoffman and Novak 1998; Mossberger, Tolbert, and Stansbury 2003; Mossberger, Tolbert, and Gilbert 2006; Ono and Zavodny 2007; Fairlie 2004; Goldfarb and Prince 2008 for example).
} 
concerns about selection bias resulting from which families decide to purchase computers I use data from the largest-ever randomized control experiment providing free personal computers to U.S. schoolchildren for home use. ${ }^{6}$ Half of over one thousand schoolchildren grades 6-10 attending 15 different schools were randomly selected to receive computers to use at home. Previous findings for all schoolchildren participating in the field experiment indicate that the randomly selected group of students receiving free computers experienced no improvement in educational outcomes relative to the control group that did not receive free computers (Fairlie and Robinson 2013). Fairlie and Robinson (2013), however, does not explore whether boys and girls use computers differently and whether these differences contribute to the gender gap in academic performance among disadvantaged schoolchildren.

Briefly previewing the results, I find that girls outperform boys not only in grades, test scores in reading and writing, and high school graduation rates, but also in numerous other educational outcomes. The results show a remarkably consistent underperformance of boys relative to girls in school, which holds across race and family resources. Using microdata from the CPS computer supplement I find that boys and girls have very similar rates of access to home computers overall and by race and income even though disparities across these groups are large. Boys and girls use computers differently, however, with boys using computers more for video games and girls using computers more for schoolwork, email and social networking, which does not differ substantially by race or income. Estimates from the random experiment, however, do not provide evidence that computers crowd out homework time and effort for disadvantaged

\footnotetext{
${ }^{6}$ If computers were exogenously assigned to children the question could be explored by simply comparing the girl-boy gap in educational outcomes among existing computer owners to the girl-boy gap in educational outcomes among existing non-computer owners. But, parents make decisions about computer purchases partly based on concerns about the non-educational uses of computers by children and partly based on the perceived educational benefits of computers to children (which might differ between boys and girls) raising concerns about selection bias.
} 
boys relative to girls, or that home computers have negative effects on grades, test scores, and other educational outcomes for boys relative to girls. Although parents, schools, and policymakers may have other concerns about how boys and girls use computers, these patterns do not appear to contribute to why disadvantaged boys do worse in school than girls.

The remainder of the paper is organized as follows. In Section 2, I describe the data sources used to examine gender differences in computer access and use. I also describe the experiment used to test for gender differences in the impacts of computers on educational outcomes. Section 3 presents estimates of gender differences in academic performance. Section 4 presents estimates of gender differences in computer access and use. Section 5 presents the experimental results for the impacts of home computers on homework time and effort and educational outcomes for boys and girls. Section 5 concludes.

\section{Data and Methods}

Data on Computer Use

Data from three national sources are used to examine whether boys and girls use computers differently. I use data from the Current Population Survey Computer and Internet Use Supplements conducted by the U.S. Bureau of Labor Statistics and Census Bureau, a time use diary study of the use of technology by children conducted by the Kaiser Family Foundation, and surveys of teenagers conducted as part of the Pew Internet and American Life Project. The combination of data from these national sources provides the first comprehensive examination of gender differences in computer use among children.

The Internet and Computer Use Supplement to the Current Population Survey (CPS), conducted by the U.S. Census Bureau and the Bureau of Labor Statistics, is representative of the 
entire U.S. population and interviews approximately 50,000 households and 130,000 individuals. The Internet and Computer Use Supplement to the CPS is the primary source of information on technology use collected by the federal government and has been conducted over the past three decades at irregular intervals. The information gathered differs in each survey. Estimates from the 2003 supplement include the latest information on computer use activities among children. The estimates reported later in Table 4 are from these CPS data. The 2011 Supplement is the latest available data, but does not allow one to examine activities of computer use among children (only adult householders). Because of the lack of published results from the survey, I use microdata from the 2011 CPS Supplement to examine overall access and use rates among boys and girls ages 5-17 ( $\mathrm{N}=23,594)$. The microdata also allow for a more detailed examination of home computer access rates among girls and boys by child and family characteristics such as the gender composition of the household, race, income, and age.

The Kaiser Family Foundation surveyed 2,002 children ages 8-18 across the country in 2008 and 2009 on their use of media including detailed information on computer use (Kaiser Family Foundation 2010). Similar surveys were conducted in 1999 and 2004 by the Kaiser Family Foundation. Information on computer use activities is also reported from national surveys conducted as part of the Pew Internet and American Life Project (see Pew Internet Project 2008a, 2008b). Surveys on numerous topics related to computer, Internet and media use are conducted regularly by the Pew Research Center. The Pew Internet Project (2008a, 2008b) studies include nationally-representative samples of 1,102 children ages 12-17 in 2007 and 2008 and 700 children ages 12-17 in 2007, respectively. To our knowledge, these three sources of data represent all of the nationally representative sources of data providing detailed information on computer use among children. 


\section{Randomized Control Experiment}

To explore the effects of personal computers on crowding out homework time and educational outcomes among disadvantaged boys and girls and whether these effects differ by gender I use data from a field experiment that provides free personal computers to schoolchildren for home use. The randomized control experiment involved 1,123 students in grades 6-10 attending 15 schools across California (see Fairlie and Robinson 2013 for more details). It represents the first field experiment involving the provision of free computers to schoolchildren for home use ever conducted, and the largest experiment involving the provision of free home computers to U.S. students at any level. The randomized control experiment removes concerns about selection bias resulting from which families decide to purchase computers. All of the students participating in the study did not have computers at baseline. Half were randomly selected to receive free computers, while the other half served as the control group. Outcomes were tracked for all participating students over an academic year.

The sample for this study includes 1,123 students enrolled in grades 6-10 in 15 different middle and high schools in 5 school districts in California. The project took place over two years: two schools participated in 2008-9, twelve schools participated in 2009-10, and one school participated in both years. The 15 schools in the study span the Central Valley of California geographically. Overall, these schools are similar in size (749 students compared to 781 students), student to teacher ratio (20.4 to 22.6), and female to male student ratio (1.02 to 1.05) as California schools as a whole (U.S. Department of Education 2011). Schools in the experiment, however, are poorer (81\% free or reduced price lunch compared with 57\%) and have a higher percentage of minority students (82\% to $73 \%$ ) than the California average reflecting the 
requirement of not having a home computer for eligibility in the experiment. Participating students also have lower average test scores than the California average (3.2 compared with 3.6 in English-Language Arts and 3.1 compared with 3.3 in Math), but the differences are not large (California Department of Education 2010).

To identify children who did not already have home computers, we conducted an in-class survey at the beginning of the school year with all of the students in the 15 participating schools. The survey, which took only a few minutes to complete, asked basic questions about home computer ownership and usage. To encourage honest responses, it was not announced to students that the survey would be used to determine eligibility for a free home computer (even most teachers did not know the purpose of the survey). In total, 7,337 students completed in-class surveys, with 24 percent reporting not having a computer at home. This rate of home computer ownership is roughly comparable to the national average: - estimates from the 2010 Current Population Survey indicate that $27 \%$ of children aged $10-17$ do not have a computer with Internet access at home (U.S. Department of Education 2011).

Any student who reported not having a home computer on an in-class survey was eligible for the study. ${ }^{7}$ All eligible students were given an informational packet, baseline survey, and consent form to complete at home. To participate, children had to have their parents sign the consent form (which, in addition to participating in the study, released future grade, test score and administrative data) and return the completed survey to the school. Of the 1,636 students eligible for the study, we received 1,123 responses with valid consent forms and completed

\footnotetext{
${ }^{7}$ Because eligibility for the study is based on not having a computer at home, our estimates capture the impact of computers on the educational outcomes of schoolchildren whose parents do not buy them on their own and do not necessarily capture the impact of computers for existing computer owners.

Schoolchildren without home computers, however, are the population of interest in considering policies to expand access.
} 
questionnaires (68.6\%). We randomized treatment at the individual level, stratified by school. In total, of the 1,123 participants, 559 were randomly assigned to the treatment group. For boys, there were 555 participants with 280 assigned to the treatment group, and for girls there were 568 participants with 279 assigned to the treatment group.

The computers provided through the experiment were purchased from or donated by Computers for Classrooms, Inc., a Microsoft-certified computer refurbisher located in Chico, California. The computers were refurbished Pentium machines with 17" monitors, modems, ethernet cards, CD drives, flash drives, Microsoft Windows, and Microsoft Office (Word, Excel, PowerPoint, Outlook). The computer came with a 1-year warranty on hardware and software during which Computers for Classrooms offered to replace any computer not functioning properly. In total, the retail value of the machines was approximately $\$ 400-500$ a unit. Since the focus of the project was to estimate the impacts of home computers on educational outcomes and not to evaluate a more intensive technology policy intervention, no training or assistance was provided with the computers. We did not provide Internet service as part of the experiment and found that about half of the students receiving computers subscribed to service.

The computers were handed out by the schools to eligible students in the late fall of the school year. Almost all of the students sampled for computers received them: we received reports of only 11 children who did not pick up their computers, and 7 of these had dropped out of their school by that time. As expected, we found that some of the control group students purchased home computers by the end of the school year. From a follow-up survey conducted at the end of the school year, we found that 27 percent of girls and 25 percent of boys in the control group purchased computers, and in most cases these computers were purchased later in the school year (thus having less potential impacts on measured outcomes). After the distribution, 
neither the research team nor Computers for Classrooms had any contact with students during the school year. In addition, many of the outcomes were collected at least 6 months after the computers were given out (for example, end-of-year standardized test scores and fourth quarter grades). Thus, it is very unlikely that student behavior would have changed for any reason other than the computers themselves (for instance, via Hawthorne effects).

Data from the experiment were collected from four main sources. First, we administered a detailed baseline survey which was required to participate in the project (as that was where consent was obtained). The survey includes detailed information on student and household characteristics. Second, we administered a follow-up survey at the end of the school year, which included detailed questions about computer ownership, homework time, and homework effort allowing for a comparison of first-stage and homework crowd-out effects. The response rates for the follow-up survey were high: 78.2 percent for boys and 76.6 percent for girls. ${ }^{8}$ Third, each school provided us with detailed administrative data on educational outcomes for all students covering the entire academic year. These administrative data include grades in all courses taken and disciplinary information. Finally, schools provided us with standardized test scores from the California Standardized Testing and Reporting (STAR) program. A major advantage of the administrative data on test scores as well as grades and other outcomes is that they are measured without any measurement error, and attrition is virtually non-existent. The collection of these datasets provides an extensive amount of information on computer ownership and educational outcomes.

\footnotetext{
${ }^{8}$ The response rates are 76.7 percent for the control group and 79.6 percent for the treatment group for boys, and 75.4 percent for the control group and 77.8 percent for the treatment group for girls.
} 


\section{Randomization and Implementation Checks}

Appendix Table 1 reports summary statistics for the treatment and control groups and provides a balance check. Balance checks are reported for the total sample, the girl sample, and the boy sample. For each sample, means for the treatment and control groups and the p-value for a t-test of equality are reported. Overall, there is very little difference between the treatment and control groups in all three samples. The only variable with a difference that is statistically significant is that treatment children are less likely to live with their mother in the boy sample (although the difference of 0.06 is small relative to the base of 0.93 ). It is likely that this one difference is caused by random chance given the large number of comparisons being made nevertheless, all of these covariates are controlled for in the regressions that follow.

As a check of the experimental implementation, I also examine whether there is a large relative increase in reported computer ownership and whether the effect is similar for boys and girls. Information on computer ownership is obtained from the follow-up survey conducted at the end of the school year. For girls, I find that $82 \%$ of the treatment group and $27 \%$ of the control group report having a computer at follow-up. For boys, the overall levels are similar and the treatment-control difference is identical, with $80 \%$ of the treatment group and $25 \%$ of the control group reporting having a computer at follow-up. While these treatment-control differences of 55 percentage points are very large, if anything they are understated because only a very small fraction of the 559 students in the treatment group did not receive one (as noted above, we had reports of only 11 students who did not pick up their computer). In fact, I find that one quarter of the boy and girl treatment groups report positive hours of computer use at home even though they report in a previous question that they do not have a computer at home and are supposed to 
skip the question. In addition, any measurement error in computer ownership would understate differences in reported ownership.

The follow-up survey also asked children a battery of questions about how much they use computers for five different types of activities at home, school, and other locations. With the resulting 15 different questions of types of use, the self-reported hours responses are noisy with many missing values and some inconsistencies in reporting. Appendix Table 2 reports the average value of responses to these questions. Overall, computer use increased for both boys and girls. This includes separate use for schoolwork, email, games, and social networking. Unfortunately, the estimates are not precise enough to identify girl-boy differences in use. With so many different categories to report hours of use there is likely to be a fair amount of measurement error in these estimates, and thus I do not place too much weight on them.

These results are suggestive of three important findings regarding first-stage effects. First, the experiment had a large effect for both boys and girls on increasing computer ownership. Second, the increase in computer ownership was similar for girls and boys. Third, the experiment also increased computer use for both boys and girls for numerous activities.

\section{Girl-Boy Differences in Academic Performance}

I first examine girl-boy differences in academic performance. Figure 1 reports average grades for boys and girls from the High School Transcript Study which is part of the National Assessment of Educational Progress (NAEP) conducted by the National Center for Educational Statistics (NCES). The latest available data is for 2009 and grades are available overall and in several different subjects. The estimates clearly indicate that girls obtain better grades than boys. They have higher overall grades than boys and obtain better grades in every core subject matter. 
The disparities are large. Even in math and science, girls obtain grades that are nearly 0.2 points higher, and in English grades are over 0.3 points higher (which is equivalent to a + or - modifier on a letter grade).

Gender differences are large among disadvantaged schoolchildren. Table 1 reports average grades by parental education and race (which are the categories available in the NAEP grade data). Boys from families with low parental education or from underrepresented minority groups have lower grades in all subjects than girls from similar families. In fact, the grade underperformance of boys relative to girls is large across all parental education groups and all racial groups.

Figure 2 reports test score data for boys and girls collected as part of the 2011 NAEP. Overall girls score better, on average, than boys on reading and writing assessment tests, similarly on math assessment tests, but slightly lower on science assessment tests. Table 2 reports test scores by school lunch eligibility and race (which are the categories available in the NAEP test score data). The girl-boy patterns in test scores across subjects (i.e. girls score higher in reading and writing, similarly in math, and slightly lower in science than boys) hold for lowincome and minority schoolchildren.

Using the NAEP data on test scores, I also examine girl and boy distributions of test scores. Figure 3 reports inverse cumulative distribution functions for each of the test scores reported in Figure 2 for both boys and girls. The distributional estimates are limited by NAEP reporting to showing the $10^{\text {th }}, 25^{\text {th }}, 50^{\text {th }}, 75^{\text {th }}$, and $90^{\text {th }}$ percentiles, but these percentiles characterize the full distribution reasonably well. Because I report inverse CDFs, the vertical difference at each of the reported points in the distribution is the equivalent to a quantile treatment effect (QTE) estimate. In addition to girls having higher average test scores in reading 
and writing, girls have higher test scores throughout the distribution. At each reported percentile girls have higher scores than boys. For math test scores, girls and boys have roughly similar scores throughout the distribution with some slight differences at the reported tails. For science test scores, the distribution for boys is slightly higher at all points.

In addition to performing better on grades, and reading and writing test scores, girls outperform boys along numerous other measures of educational outcomes. Girl-boy disparities in many of these measures are not as well-known as those for grades, high school graduation rates, and college attendance. Appendix Table 3 provides evidence of consistent and sizeable gender disparities in several educational outcomes starting with outcomes relevant to school entry and ending with high school graduation.

The evidence clearly indicates that boys are doing worse in school than girls. Schoolchildren from disadvantaged families are no exception, with minority and low-income boys having lower grades in all subjects and test scores in some subjects than girls. Although some of these differences in academic performance have received attention recently, we know relatively little about differences in computer access, use, and a broader set of after-school time investments made by boys and girls.

\section{Girl-Boy Differences in Computer Access and Use}

Microdata from the computer supplement to the 2011 CPS is first used to explore whether girls and boys have similar levels of access to computers at home. Table 3 reports home computer access rates for girls and boys. Overall, boys and girls have identical rates of access to computers at home. The lack of differences by gender is not simply due to boys and girls living in the same households. Even in households with only boys or only girls access rates are 
identical. Among low-income families and disadvantaged minorities, boys and girls also have similar access rates to home computers. This finding of lack of girl/boy differences in computer access differs substantially from the large differences found by race or income (see Hoffman and Novak 1998; Mossberger, Tolbert, and Stansbury 2003; Ono and Zavodny 2003b; Fairlie 2004; Goldfarb and Prince 2008 for example). Ruling out gender differences in access to home computers is important because it focuses the analysis on differential use of computers between boys and girls, which is examined next.

Data from three national sources are used to examine whether disadvantaged boys and girls use computers differently. I use microdata from the 2003 CPS Computer and Internet Use Supplement, microdata from surveys of teenagers conducted as part of the Pew Internet and American Life Project, and a time use diary study of the use of technology by children conducted by the Kaiser Family Foundation. Table 4 reports gender differences in use. Focusing on how boys and girls use computers reveals some interesting differences. I find consistent evidence of four main patterns across the datasets. First, I find that girls are more likely than boys to use computers for schoolwork (although these differences are not large). Second, boys spend more time playing video games on computers than do girls. Third, I find some evidence that girls use computers more for social networking, email, and other communication activities. Finally, these patterns are similar for low-income and high-income children.

These results provide some evidence that boys and girls use computers differently, but it is not clear whether these differences lead to differential effects of home computers on crowding out homework and educational outcomes, and thus contribute to the gender achievement gap. Unfortunately, this question is not an easy one to answer empirically. One possibility is to conduct an experiment in which computers are randomly taken away from schoolchildren who 
already own them and examine their subsequent academic performance. Another approach, which is much more feasible, is to conduct a random experiment providing computers to schoolchildren who do not already own them and examine their subsequent academic performance. ${ }^{9}$ I take this approach next.

\section{Girl-Boy Differences in Impacts of Computers on Crowding Out Homework and}

\section{Educational Outcomes}

In this section, I examine whether computers crowd out homework time and effort differently for boys and girls, and whether computers have differential impacts on the educational outcomes of boys and girls. Recent research focusing on all children finds mixed results on the impacts of home computers on educational outcomes, but none of these studies focus on differential impacts by gender and their implications for the gender gap in academic achievement. ${ }^{10}$ To examine whether home computers have differential educational impacts for boys and girls using the experimental data, I can simply calculate treatment-control differences in mean values of each measure for the boy and girl samples separately. To improve precision and confirm the robustness of the results to randomization, however, I estimate several regressions for homework time and educational outcomes. The regression equation is straightforward in the context of the random experiment:

(1) $Y_{i}=\alpha+\beta^{G} T_{i} G_{i}+\beta^{B} T_{i} B_{i}+\theta G_{i}+\delta \boldsymbol{X}_{i}+\varepsilon i$,

\footnotetext{
${ }^{9}$ The alternative approaches also have different implications for external validity. An experiment taking the former approach focuses on a more advantaged group whereas as an experiment taking the latter approach focuses on a less advantaged group. The two groups may use computers differently. ${ }^{10}$ See Schmitt and Wadsworth (2004); Fairlie (2005); Fuchs and Woessmann (2004); Fiorini (2010); Beltran, et al. (2010); Malamud and Pop-Eleches (2010); Beuermann et al. (2012); Fairlie and Robinson (2013); Vigdor, et al. (2014); Falck, et al. 2015 for example, and see Bulman and Fairlie (2015) for a recent review of the literature.
} 
where $Y_{i}$ is the outcome for student $i$ (e.g. grade), $T_{i}$ is an indicator variable for being in the treatment group, $G_{i}$ is an indicator for girls, $B_{i}$ is an indicator for boys, $\boldsymbol{X}_{i}$ includes the baseline characteristics such as demographic and family characteristics reported in Appendix Table 1, and $\varepsilon_{i}$ is an error term. The separate effects of becoming eligible for a free computer or the "intent-totreat" estimate of the giveaway program are captured by $\beta^{\mathrm{G}}$ for girls and $\beta^{\mathrm{B}}$ for boys, respectively. The differential impact of home computers on educational outcomes between girls and boys is equal to $\beta^{\mathrm{G}}-\beta^{\mathrm{B}}$. All specifications are estimated using OLS and robust standard errors are reported with adjustments for multiple observations per student (i.e. clustered by student) when needed for grades. ${ }^{11}$ The standard error for $\beta^{\mathrm{G}}-\beta^{\mathrm{B}}$ is estimated from the re-specified regression:

(2) $Y_{i}=\alpha+\beta^{B} T_{i}+\left(\beta^{G-} \beta^{B}\right) T_{i} G_{i}+\theta G_{i}+\delta \boldsymbol{X}_{i}+\varepsilon i$.

Marginal effects estimates are similar from probit and logit models, and are thus not reported.

I first examine whether obtaining a computer crowds out homework time and effort for boys relative to girls using information collected from our follow-up survey. Table 5 reports estimates of home computer effects on self-reported measures of time spent doing homework, turning assignments in on time, and how much time is spent on the last essay or report. I report estimates of treatment effects separately for boys and girls and the difference between the two (which is estimated in a separate regression to obtain the standard error). Home computers do not crowd out homework time for boys relative to girls. The point estimate on the girl-boy treatment is actually negative, although small and statistically insignificant. Obtaining a personal computer

\footnotetext{
${ }^{11}$ For all regressions for each educational outcome, I include controls for the sampling strata (school*year) in addition to the controls listed in Appendix Table 1. To avoid dropping observations, for each control variable, I create a dummy equal to 1 if the variable is missing for a student and code the original variable as a 0 (so that the coefficients are identified from those with non-missing values). Estimates are similar when I instead exclude these observations (there are only a few missing values).
} 
also has no negative effect on whether boys report turning in homework on time relative to girls. Finally, the computers did not appear to result in boys spending less time working on essays than girls.

Overall, there is no evidence indicating that computers crowd out homework time and effort for boys relative to girls. Another interesting finding is that in absolute terms I also do not find evidence that computers crowd out homework time and effort among boys (or girls).

Turning to educational outcomes, I examine whether home computers have a negative effect on grades, test scores, total courses completed and tardies obtained from administrative data from each of the schools. Table 6 reports estimates of the separate effects of home computers on grades for boys and girls and the difference between the two. ${ }^{12}$ Panel A reports estimates of treatment effects on overall grades and grades in academic subjects (i.e. math, English, social studies, science) for boys and girls and the difference between the two. For the grade regressions, I pool the quarter 3 and 4 grades together. I find similar results when I estimate separate regressions for quarter 3 and quarter 4 . I also include controls for quarter 1 grades, the subject and quarter in the regressions. Grades are coded as A-4, B-3, C-2, D-1, F-0. +/- modifiers are set equal to 0.33 points. In all cases, I find no evidence of a positive or negative effect of computers on grades for boys or girls. ${ }^{13}$ Similarly, home computers do not have a differential effect on grades for boys and girls.

\footnotetext{
${ }^{12}$ I focus on grades first because of their importance in determining high school graduation and college admissions (Betts and Morrell 2009).

${ }^{13}$ LATE (or IV) estimates would be about twice as large (since the difference in computer usage is 55 percentage points). I do not report these estimates, however, because I cannot technically scale up the coefficients with the IV estimator because of differential timing of purchasing computers over the school year by the control group (two thirds of the control group with a home computer at follow-up obtained this computer after the fall). The finding that 80-82 percent of the treatment group reports having a computer at the end of the school year also creates difficulty in scaling up the ITT estimates because I know that essentially all treatment students picked up their computers and that many of the treatment
} 
In Columns 3-4, I supplement the overall grade estimate by focusing on the effects of home computers on the pass/fail part of the grade distribution. In all of the schools, a grade of Dor higher is considering passing and provides credit towards moving to the next grade level and graduation. Again, I find no evidence of a differential effect of home computers between boys and girls. Expanding the distribution even further, I focus on the effects of home computers on the probability of obtaining a grade of B or higher (columns 5-6) and a grade of A or higher (columns 7-8). In both cases, I find no evidence of a differential effect of home computers for boys and girls. Estimates from quantile regressions for the full post-treatment achievement distribution confirm these findings (not reported). I do not find evidence of a clear pattern of differential treatment effects across the distribution.

I also examine whether treatment effects differ by subject. The finding for overall grades holds when examining courses separately by subject. Girls perform better in all subjects than boys, but home computers have no differential effect, either negative or positive, on grades for any subject. The lack of a negative relative effect for boys suggests that home computers are not contributing to why boys have lower grades in all subjects than girls. The finding holds for both average grades and along the pass/fail margin.

Related to this issue, I examine whether there are differential treatment effects across the pre-treatment grade distribution. There might be negative relative treatment effects for boys for some parts of the distribution that cannot be identified focusing on the average treatment effect. I estimate the following regression:

(3) $Y_{i}=\beta_{p c} * D_{i p} * C_{i}+\beta_{p t} * D_{i p} * T_{i}+\delta \mathbf{X}_{i}+\varepsilon_{i}$

group reporting not having a computer at follow-up indeed had a computer at home (based on subsequent conversations with the students by principals). For these reasons I focus on the ITT estimates. 
In the regression, $D_{i p}$ is an indicator for whether individual $i$ is in the $p$ th percentile of the pretreatment GPA distribution. Percentiles are calculated within each school and are restricted to 20 different percentile categories. $C_{i}$ is an indicator for the control group, and $T_{i}$ is an indicator for the treatment group. Thus, $\beta_{p c}$ and $\beta_{p t}$ are estimates of the relationship between pre- and posttreatment performance in the control and treatment groups, respectively, and the difference, $\beta_{p t}-\beta_{p c}$ provides an estimate of the treatment effect at the $p$ th percentile. $\mathbf{X}_{i}$ is a minimal set of controls, including only subject and quarter indicators (so that the coefficients represent the unconditional relationship between pre- and post-performance for the treatment and control groups). $\beta_{p c}$ and $\beta_{p t}$ are reported in Figure 4a for girls and Figure $4 \mathrm{~b}$ for boys. Standard errors are clustered at the individual level, and the 95\% confidence interval of the difference between the treatment and control groups is plotted.

The estimates displayed in the figures indicate that treatment effects are indistinguishable from zero at almost all points of the pre-treatment grade distribution for both girls and boys. Thus, I do not find evidence of differential effects of home computers for boys and girls across the distribution.

I also estimate the impacts of home computers performance on the California Standardized Testing and Reporting (STAR) Program tests. As part of the STAR Program, all California students are required to take standardized tests for English-Language Arts and math each spring. For regressions in which test scores are the dependent variable, I focus on two key measures. First, I report estimates for a standardized test score based on raw values. These test scores are normalized to have mean 0 and standard deviation 1 . I also report estimates for an indicator of proficiency. This variable is coded as 1 if the student receives a 4 or 5 (out of 5) on the test, and 0 otherwise. Proficiency and advanced scores meet state standards and are important 
for schools to satisfy Adequate Yearly Progress (AYP) as part of the No Child Left Behind Act.

Table 7 reports estimates of the effects of home computers on test scores in

English/Language Arts and mathematics. For both test scores, and whether I use a standardized test score or an indicator for meeting proficiency levels, I do not find evidence that home computers have a differential effect for boys and girls.

In addition to not finding a differential effect between girls and boys at the proficiency level I also do not find effects throughout the distribution. Plots of inverse cumulative distribution functions (CDFs) for both boys and girls reveal substantial overlap between the treatment and control groups for both test scores. ${ }^{14}$ The lack of treatment effects across the distribution implies that there are no differential effects between boys and girls. Similarly, Figures 5 and 6 examine the effects of home computers on STAR scores by prior achievement levels. Again, there is no discernible effect at almost any point in the pre-treatment STAR distribution. The finding holds for both English/Language Arts and math test scores. These figures suggest minimal effects of computers across the pre-treatment ability distribution and rule out the possibility that the null estimates of average treatment effects are due to offsetting positive and negative treatment effects at different parts of the pre-treatment achievement distribution. Most importantly, the lack of treatment effects for both boys and girls implies no differential effects throughout the distribution.

I also examine the effects of home computers on total courses completed and number of tardies. Estimates are reported in Columns 5-7 of Table 7. I find no evidence of a differential effect of home computers on total courses completed in the $3^{\text {rd }}$ and $4^{\text {th }}$ quarters of the academic

\footnotetext{
${ }^{14}$ I examined inverse CDFs because the STAR scores are lumped into only 5 bins and thus I cannot estimate quantile treatment effects.
} 
year. Estimates from the experiment also do not indicate that differential effects of home computers explain boy-girl differences in being tardy for school.

For all of the educational outcomes examined there is no evidence of a negative relative effect for boys suggesting that home computers and their use cannot explain why boys generally do worse in school than girls.

\section{Conclusions}

The results from this study provide the first evidence in the literature on whether disadvantaged boys and girls use computers differently, whether home computers crowd out homework time differently for boys and girls, and whether home computers have differential effects on educational outcomes among boys and girls. Although estimates from the CPS indicate that girls and boys have similar rates of access to home computers, evidence from several sources of data indicate that boys use computers differently than girls. Boys use computers less for schoolwork and more for playing games, but less for communication such as through social networking, email and instant messaging, than girls. Using data from a large field experiment that randomly provides free personal computers to schoolchildren for home use, I test the hypothesis that these gender differences in computer use partly explain why boys generally do worse than girls in school. I do not find evidence that computers crowd out homework time and effort more for boys than for girls. Examining impacts on grades, test scores and additional educational outcomes, the evidence does not indicate negative effects of home computers for boys relative to girls. I do not find differential effects at notable points in the distribution such as pass rates and meeting proficiency standards, or throughout the distribution of post-treatment outcomes. 
Disadvantaged boys and girls differ in how they use computers, but these differences do not appear to lead to different levels of crowding out of homework and study time, and do not ultimately lead to different grades, test scores and other educational outcomes. Thus, gender differences in time investments in how personal computers are used at home do not appear to contribute to the achievement gap between disadvantaged boys and girls. This finding has implications for the general view that girls are more "self-disciplined" than are boys. Both girls and boys are found here to use computers for non-educational activities, but for both boys and girls these activities do not appear to crowd out homework time and negatively affect performance in school.

For the broader picture of the girl-boy achievement gap, identifying, or ruling out, potential explanations for why boys are doing worse in school than girls is extremely important. Some policy recommendations include increasing the number of male teachers at young grades, all-boy classrooms, more hands-on activities, and more frequent or longer recesses. Recent trends in educational outcomes do not show relative improvement for boys, and differences between boys and girls are quite large. The girl-boy difference in grades of 0.2 grade points is only slightly smaller than the white-Latino difference of 0.25 grade points and half the whiteblack difference of 0.4 grade points. The racial achievement gap, however, has attracted considerably more attention in the literature and policy arena (e.g. Jencks and Phillips 1998). Further research on the causes of gender differences in educational outcomes especially among disadvantaged and low-income children is clearly needed. 


\section{References}

Anderson, Michael. 2008. "Multiple Inference and Gender Differences in the Effects of Early Intervention: A Reevaluation of the Abecedarian, Perry Preschool, and Early Training Projects." Journal of the American Statistical Association, 103(484): 1481-1495.

Antecol, Heather, Ozkan Eren, and Serkan Ozbeklik. 2013. The effect of Teach for America on the distribution of student achievement in primary school: Evidence from a randomized experiment, Economics of Education Review, 37: 113-125.

Beltran, Daniel O., Kuntal K. Das, and Robert W. Fairlie. 2010. "Home Computers and Educational Outcomes: Evidence from the NLSY97 and CPS," Economic Inquiry 48(3): 771792.

Betts, Julian and Darlene Morell. 1999. "The Determinants of Undergraduate Grade Point Average: The Relative Importance of Family Background, High School Resources, and Peer Group Effects." Journal of Human Resources, Vol. 34, No. 2: 268-93.

Beuermann, Diether W., Julián P. Cristia, Yyannu Cruz-Aguayo, Santiago Cueto, and Ofer Malamud. 2012. "Home Computers and Child Outcomes: Short-Term Impacts from a Randomized Experiment in Peru," Inter-American Development Bank Working Paper No. IDBWP-382.

Bulman, George, and Robert W. Fairlie. 2015. "Technology and Education: Computers, Software, and the Internet " Handbook of the Economics of Education, Volume 5, eds. Rick Hanushek, Steve Machin, and Ludger Woessmann, North-Holland.

California Department of Education. 2010. 2010 STAR Test Results: California STAR Program, http://star.cde.ca.gov/star2010/

Cornwell, Christopher M., David B. Mustard, and Jessica Van Parys. 2013. "Non-cognitive Skills and the Gender Disparities in Test Scores and Teacher Assessments: Evidence from Primary School." Journal of Human Resources, 48(1): 236-264.

Dee, Thomas S. 2007. "Teachers and the Gender Gaps in Student Achievement," Journal of Human Resources, XLII(3): 528-554.

Duckworth, Angela Lee, and Martin E. P. Seligman. 2006. "Self-Discipline Gives Girls the Edge: Gender in Self-Discipline, Grades, and Achievement Test Scores," Journal of Educational Psychology, 98(1): 198-208.

Fairlie, Robert W. 2004. "Race and the Digital Divide," Contributions to Economic Analysis \& Policy, The Berkeley Electronic Journals 3(1), Article 15: 1-38.

Fairlie, Robert W. 2005. "The Effects of Home Computers on School Enrollment," Economics of Education Review 24(5): 533-547. 
Fairlie, Robert W., and Jonathan Robinson. 2013. "Experimental Evidence on the Effects of Home Computers on Academic Achievement among Schoolchildren." American Economic Journal: Applied Economics, 5(3): 211-40.

Falck, Oliver, Constantin Mang, and Ludger Woessmann. 2015. "Virtually No Effect? Different Types of Computer Use and the Effect of Classroom Computers on Student Achievement," CESifo Working Paper No. 5266.

Figlio, David, Mark Rush, and Lu Yin. 2013. "Is It Live or Is It Internet? Experimental Estimates of the Effects of Online Instruction on Student Learning." Journal of Labor Economics 31(4): 763-784.

Fiorini, M. 2010. “The Effect of Home Computer Use on Children's Cognitive and NonCognitive Skills,” Economics of Education Review 29: 55-72.

Fuchs, Thomas, and Ludger Woessmann. 2004. "Computers and Student Learning: Bivariate and Multivariate Evidence on the Availability and Use of Computers at Home and at School." CESifo Working Paper No. 1321.

Goldfarb, Avi, and Jeffrey Prince. 2008. "Internet Adoption and Usage Patterns are Different: Implications for the Digital Divide." Information Economics and Policy 20(1), 2-15.

Goldin, Claudia, Lawrence Katz, and Ilyana Kuziemko (2006). "The Homecoming of American College Women: The Reversal of the College Gender Gap." Journal of Economic Perspectives.

Gordo, Blanca. 2008. Disconnected: A Community and Technology Needs Assessment of the Southeast Los Angeles Region. Center for Latino Policy Research, UC Berkeley Report.

Hargittai, Eszter. 2007. "Whose Space? Differences among Users and Non-Users of Social Network Sites," Journal of Computer-Mediated Communication 13(1): 276-297.

Hoffman, Donna L. and Thomas P. Novak. 1998. "Bridging the Racial Divide on the Internet." Science 17 April: 390-391.

Jencks, Christopher, and Meredith Phillips. 1998. The Black-White Test Score Gap, Washington, DC: Brookings Institution Press.

Kaiser Family Foundation. 2010. Generation $M^{2}$ : Media in the Lives of 8-to 18-Year Olds. Kaiser Family Foundation Study.

Karpinski, A.C. 2009. “A description of Facebook use and academic performance among undergraduate and graduate students," paper presented at the Annual Meeting of the American Educational Research Association, San Diego, Calif. 
Lazarus, Wendy. 2006. California Competes: Deploying Technology to Help California Youth Compete in a 21st-Century World: A Three-Point Digital Opportunity Action Plan, Children's Partnership Report.

Malamud, Ofer, and Cristian Pop-Eleches. 2011. "Home Computer Use and the Development of Human Capital," Quarterly Journal of Economics 126: 987-1027.

Malamud, Ofer and Diane Schanzenbach (2007). "The Disparity between Boys' Performance and Teacher Evaluations during Elementary School." University of Chicago working paper.

Mossberger, Karen. 2008. “Toward Digital Citizenship: Addressing Inequality in the Information Age,” in Handbook of Internet Politics, Andrew Chadwick and Philip Howard, eds. London: Routledge.

Mossberger, K., C. Tolbert, and M. Stansbury. 2003. Virtual Inequality: Beyond the Digital Divide. Georgetown University Press, Washington, DC.

Mossberger, K., C. Tolbert, and M. Gilbert. 2006. "Race, Place, and Information Technology," Urban Affairs Review, 41(5): 583-620.

National Telecommunications and Information Administration. 2011. Digital Nation: Expanding Internet Usage, Washington, D.C.: U.S. Department of Commerce, National Telecommunications and Information Administration.

National Center for Educational Statistics. 2011. Digest of Educational Statistics 2011, Washington, D.C.: U.S. Department of Education, National Center for Educational Statistics.

National Center for Educational Statistics. 2012. Youth Indicators 2011: America's Youth: Transitions to Adulthood, Washington, D.C.: U.S. Department of Education, National Center for Educational Statistics.

Ono, Hiroshi, and Madeline Zavodny. 2003. “Gender and the Internet," Social Science Quarterly 84(1): 111-121.

Ono, Hiroshi, and Madeline Zavodny. 2007. "Digital Inequality: A Five Country Comparison Using Microdata,” Social Science Research, 36 (September 2007): 1135-1155.

Pasek, Josh, and Eszter Hargittai. 2009. "Facebook and academic performance: Reconciling a media sensation with data," First Monday, Volume 14, Number 5 - 4.

Pew Internet Project. 2008. Teens, Video Games, and Civics, Washington, D.C.: Pew Internet \& American Life Project.

Pew Internet Project. 2008. Writing, Technology and Teens, Washington, D.C.: Pew Internet \& American Life Project. 
Puma, Michael J., Duncan D. Chaplin, and Andreas D. Pape. 2000. E-Rate and the Digital Divide: A Preliminary Analysis from the Integrated Studies of Educational Technology. Urban Institute.

Servon, Lisa. 2002. Bridging the Digital Divide: Community, Technology and Policy (Blackwell).

Servon, Lisa J., and Marla K. Nelson. 2001. Community Technology Centers: Narrowing the Digital Divide in Low-Income, Urban Communities, Journal of Urban Affairs, 23(3-4): 279290.

Schmitt, John, and Jonathan Wadsworth. 2006. "Is There an Impact of Household Computer Ownership on Children's Educational Attainment in Britain?" Economics of Education Review, 25: 659-673.

Sundstrom, William A. 2004. "The College Gender Gap in Comparative Perspective, 19502000," Santa Clara University, Department of Economics Working Paper.

U.S. Department of Education. 2011. “School Locator,” National Center for Educational Statistics, http://nces.ed.gov/ccd/schoolsearch/

Universal Services Administration Company. 2013. Annual Report

http://www.usac.org/about/tools/publications/annual-reports/default.aspx.

Vigdor, Jacob L., Helen F. Ladd, and Erika Martinez. 2014. "Scaling the Digital Divide: Home Computer Technology and Student Achievement,” Economic Inquiry. 52(3): 1103-1119.

Zavodny, Madeline. 2006. "Does Watching Television Rot Your Mind? Estimates of the Effect on Test Scores,” Economics of Education Review 25: 565-573. 


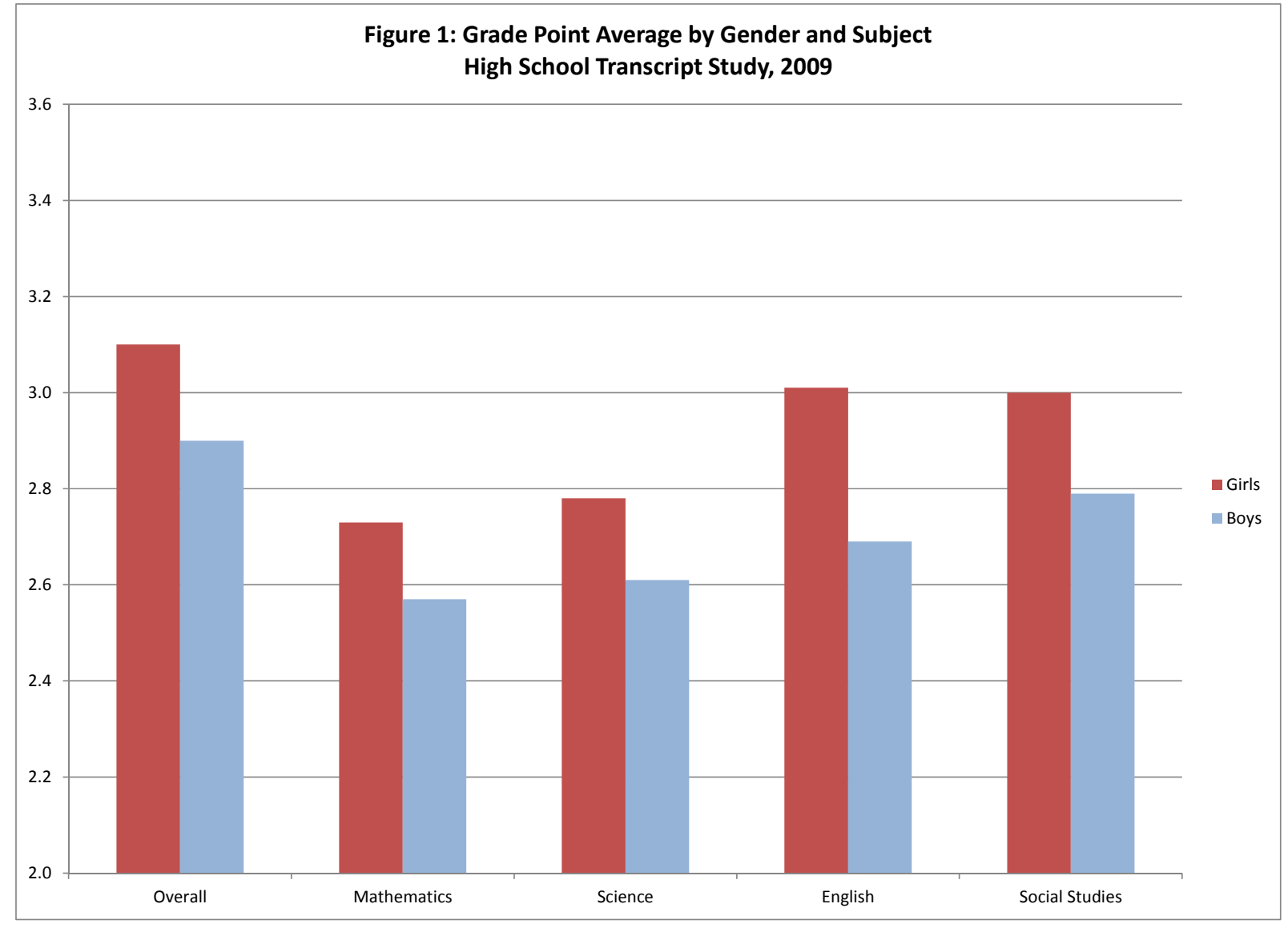




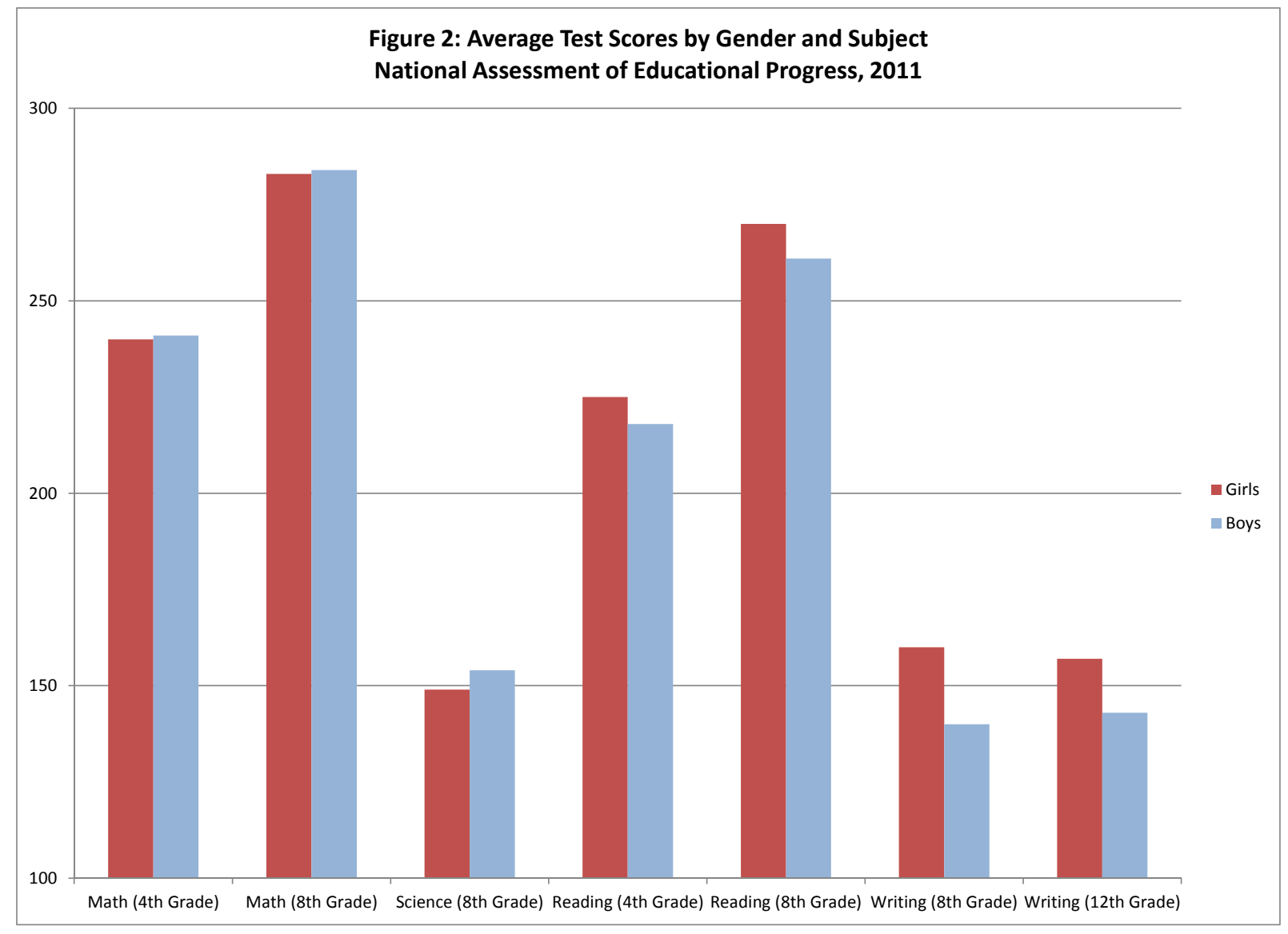


Figure 3.A: Inverse CDF for Test Scores (Reading and Writing) National Assessment of Educational Progress, 2011
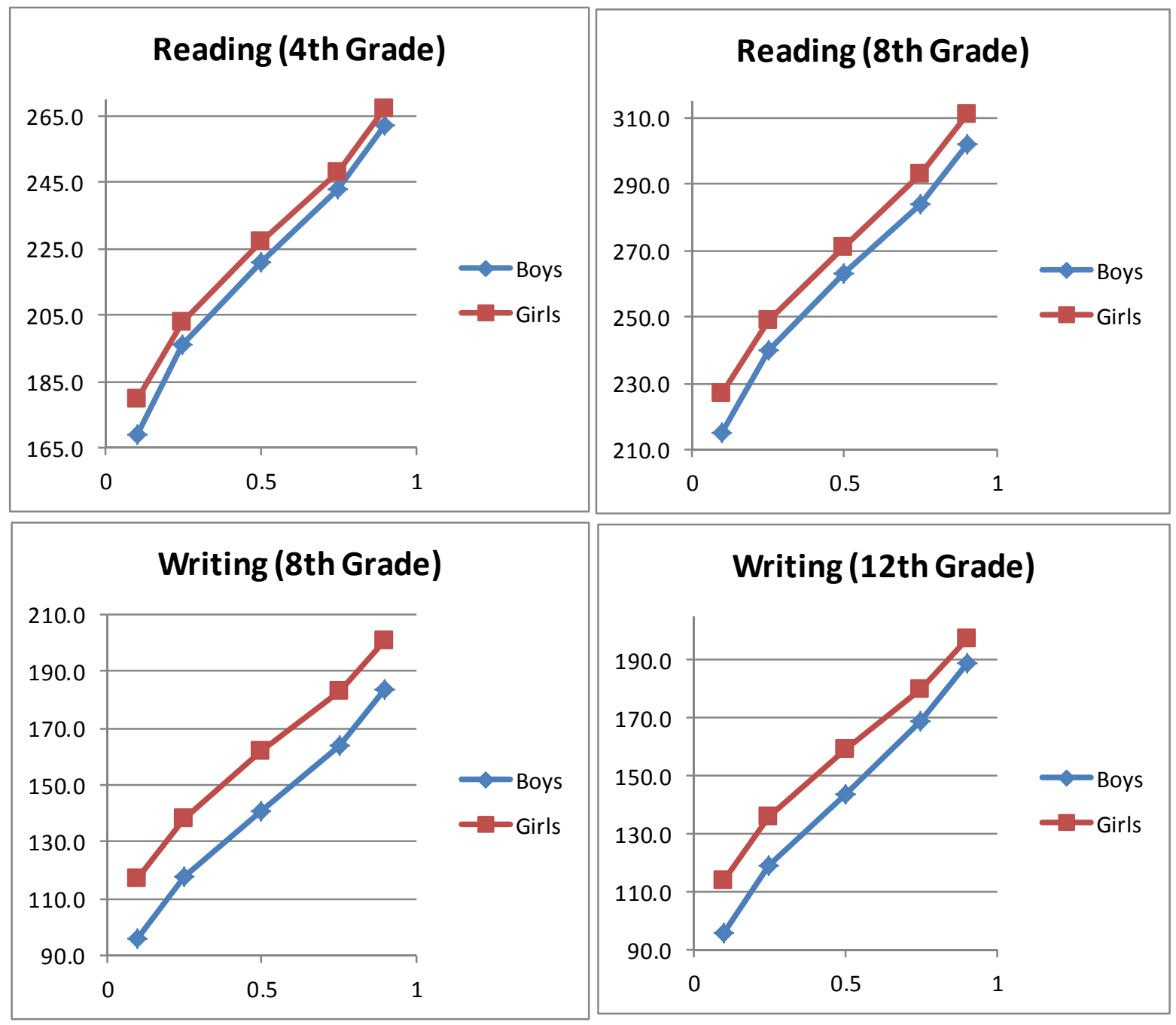
Figure 3.B: Inverse CDF for Test Scores (Math and Science)

National Assessment of Educational Progress, 2011
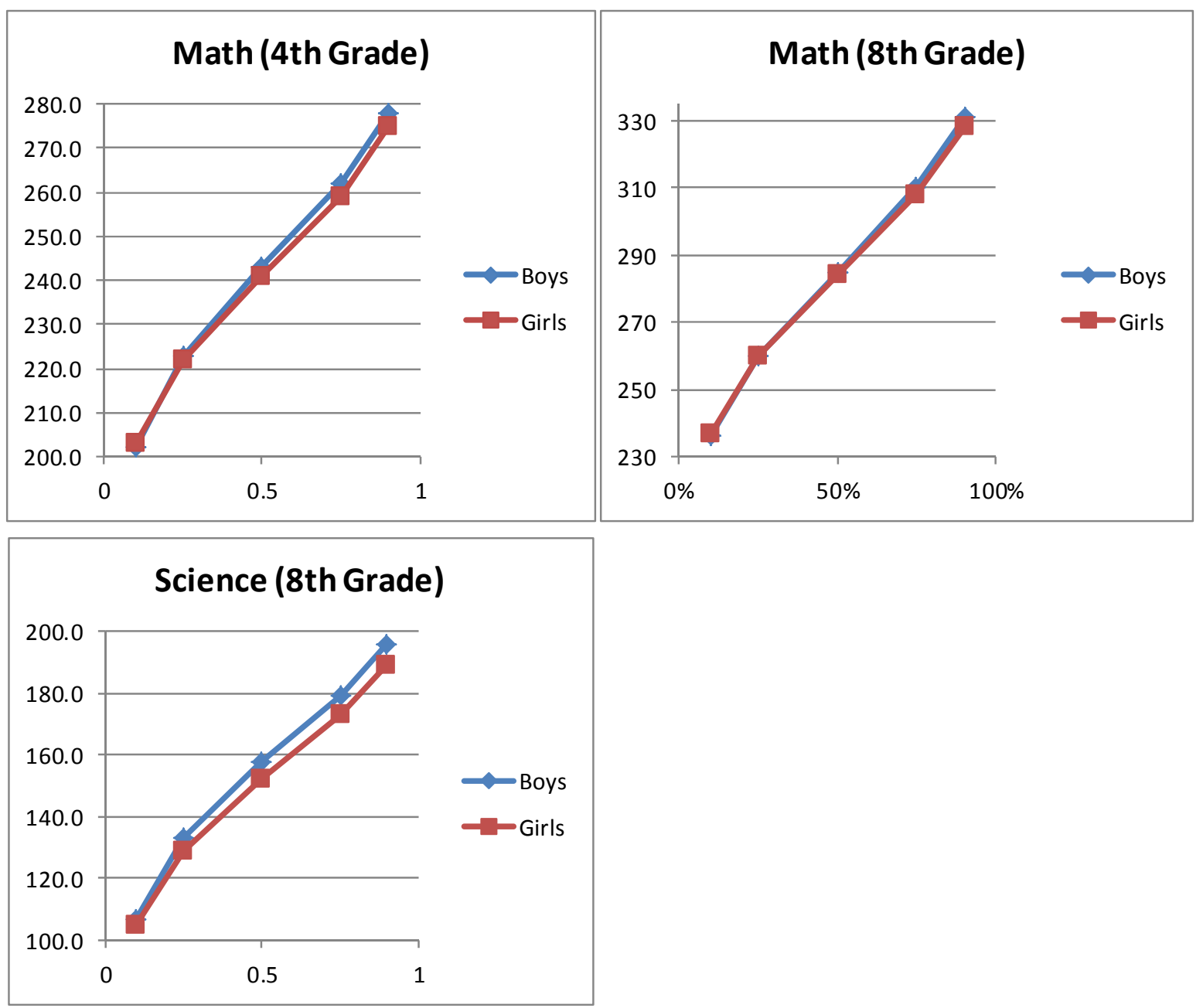


\section{Figure 4. Post-Treatment Grades by Pre-Treatment GPA Percentile}

Panel A. Girls

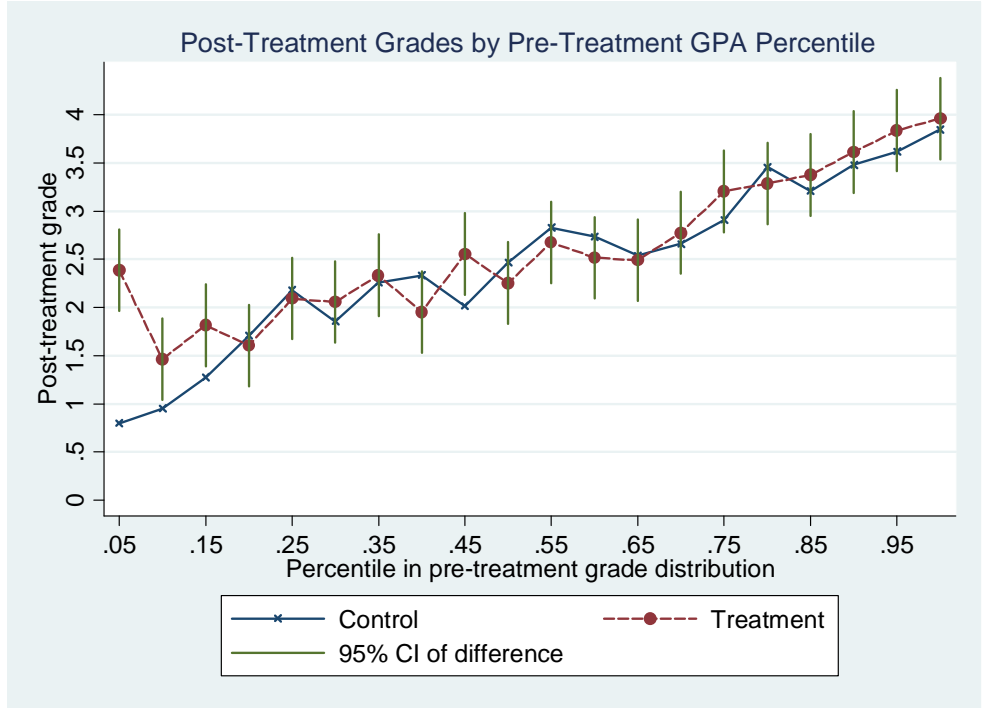

Panel B. Boys

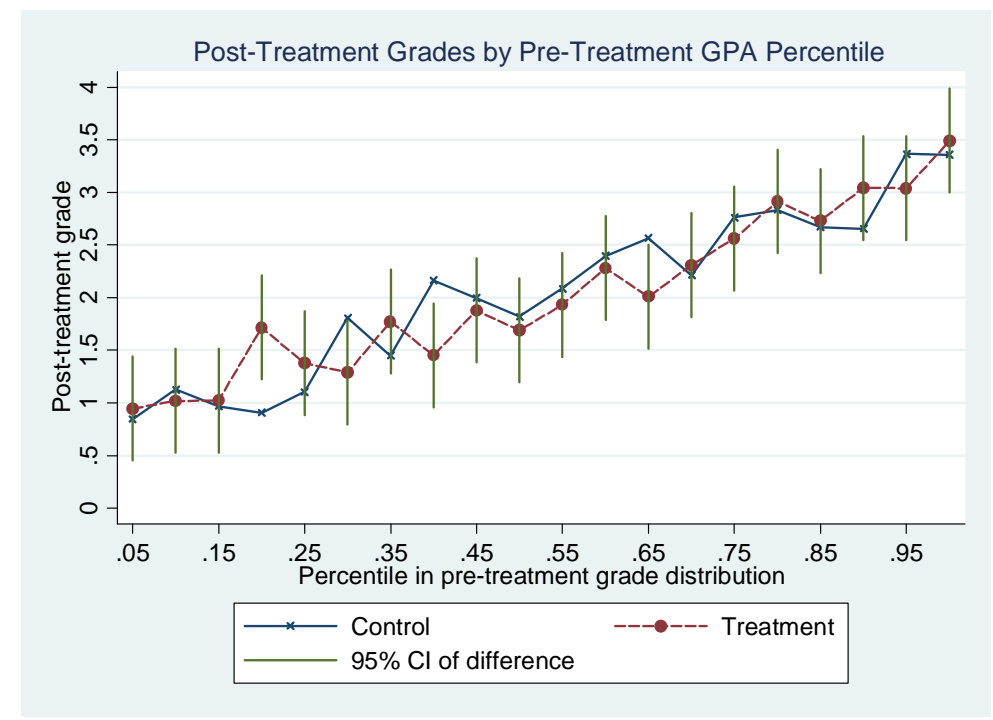

Notes: The graph shows estimated coefficients from a regression of post-treatment (quarters 3 and 4) grades on interactions between treatment and pre-treatment GPA percentile (in quarter 1, before the computers were given out). The vertical line is a 95\% confidence interval for the difference between the treatment and control groups, at each percentile. See text for more details. 


\section{Figure 5. Post-Treatment English/Language Arts STAR scores by Pre-Treatment Star Percentiles}

Panel A. Girls

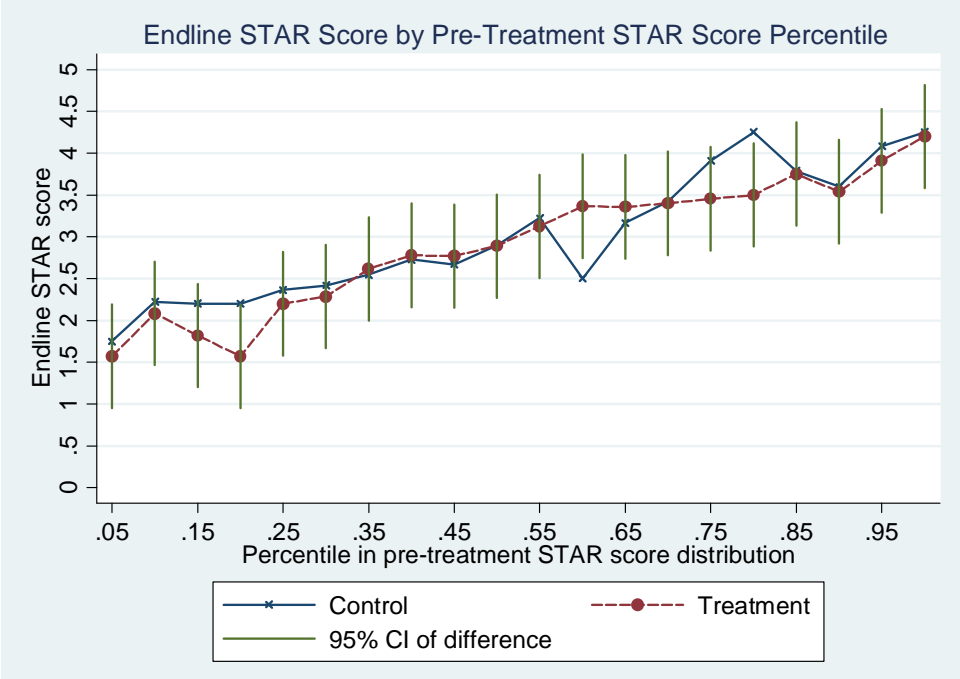

Panel B. Boys

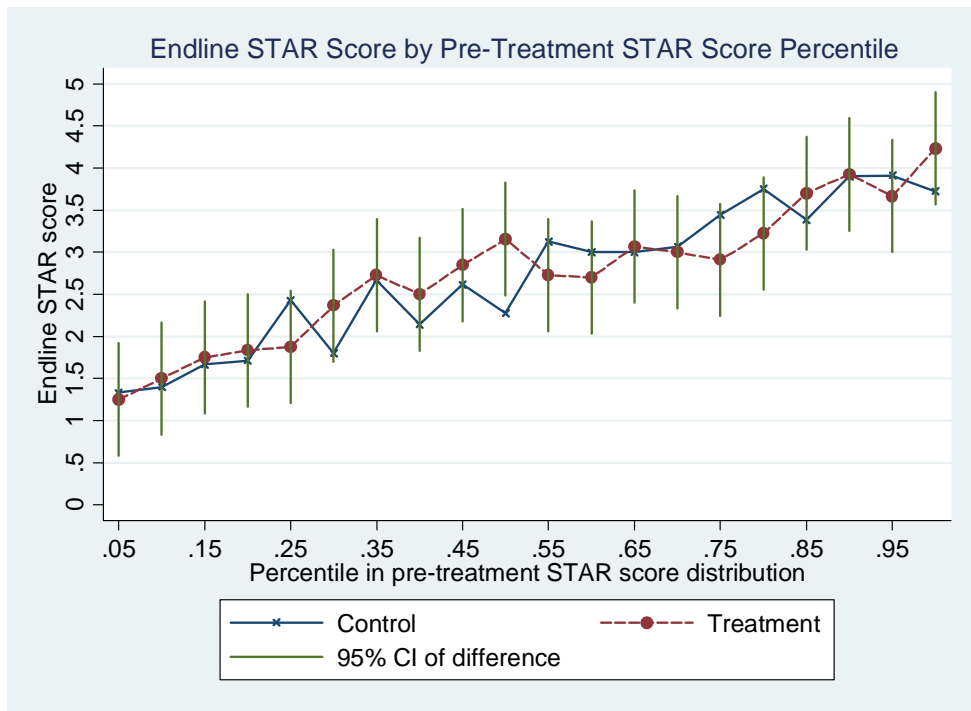

Notes: The graph shows estimated coefficients from a regression of endline STAR scores on interactions between treatment and pre-treatment STAR scores. The vertical line is a 95\% confidence interval for the difference between the treatment and control groups, at each percentile. See text for more details. 
Figure 6. Post-Treatment Math STAR scores by Pre-Treatment Star Percentiles

Panel A. Girls

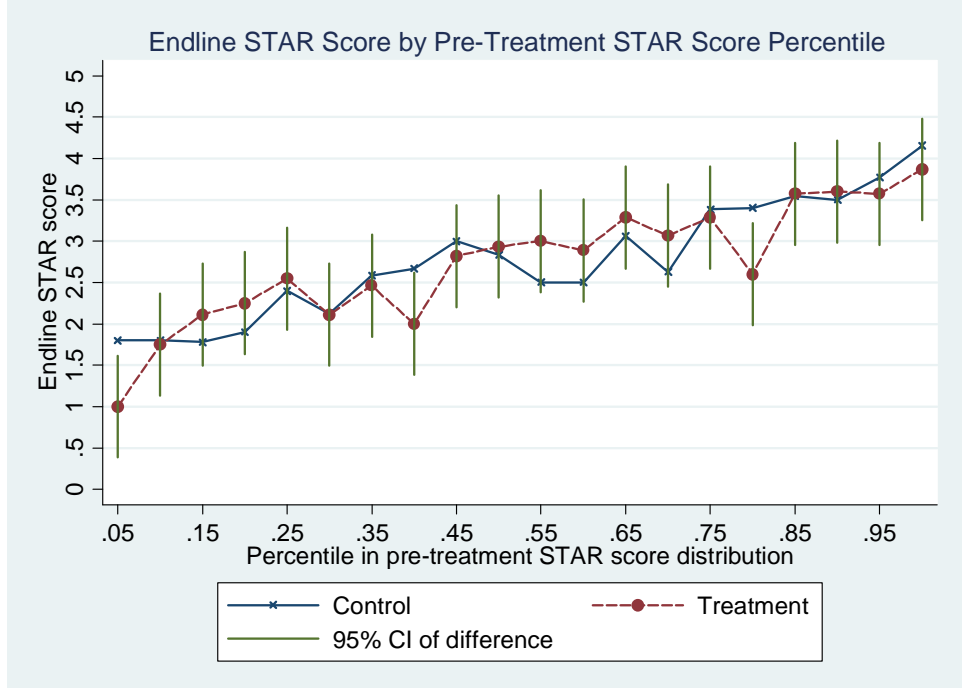

Panel B. Boys

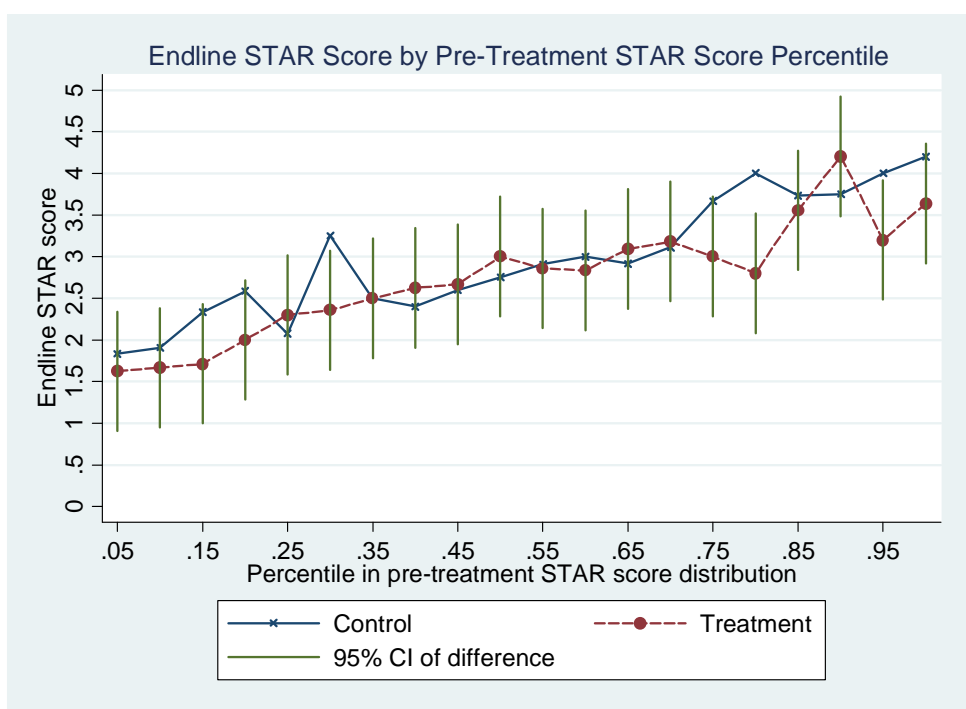

Notes: The graph shows estimated coefficients from a regression of endline STAR scores on interactions between treatment and pre-treatment STAR scores. The vertical line is a 95\% confidence interval for the difference between the treatment and control groups, at each percentile. See text for more details. 
Table 1. Grade Point Average by Gender, Parental Education and Race

\begin{tabular}{|c|c|c|c|}
\hline & Girls & Boys & $\begin{array}{c}\text { Girl-Boy } \\
\text { Difference }\end{array}$ \\
\hline \multicolumn{4}{|l|}{ Grade Point Average (Overall) } \\
\hline All Students & 3.10 & 2.90 & 0.20 \\
\hline Parental Education: High School Dropout & 2.88 & 2.75 & 0.13 \\
\hline Parental Education: Graduated High School & 2.98 & 2.77 & 0.21 \\
\hline Parental Education: Graduated College & 3.27 & 3.04 & 0.23 \\
\hline Race: White & 3.20 & 2.98 & 0.22 \\
\hline Race: Black & 2.79 & 2.57 & 0.22 \\
\hline Race: Hispanic & 2.91 & 2.75 & 0.16 \\
\hline Race: Asian & 3.37 & 3.15 & 0.22 \\
\hline \multicolumn{4}{|l|}{ Grade Point Average (Mathematics) } \\
\hline All Students & 2.73 & 2.56 & 0.17 \\
\hline Parental Education: High School Dropout & 2.51 & 2.42 & 0.09 \\
\hline Parental Education: Graduated High School & 2.61 & 2.43 & 0.18 \\
\hline Parental Education: Graduated College & 2.92 & 2.72 & 0.20 \\
\hline Race: White & 2.84 & 2.63 & 0.21 \\
\hline Race: Black & 2.41 & 2.23 & 0.18 \\
\hline Race: Hispanic & 2.51 & 2.43 & 0.08 \\
\hline Race: Asian & 3.09 & 2.94 & 0.15 \\
\hline \multicolumn{4}{|l|}{ Grade Point Average (Science) } \\
\hline Average & 2.78 & 2.61 & 0.17 \\
\hline Parental Education: High School Dropout & 2.52 & 2.43 & 0.09 \\
\hline Parental Education: Graduated High School & 2.64 & 2.47 & 0.17 \\
\hline Parental Education: Graduated College & 2.99 & 2.78 & 0.21 \\
\hline Race: White & 2.89 & 2.70 & 0.19 \\
\hline Race: Black & 2.47 & 2.24 & 0.23 \\
\hline Race: Hispanic & 2.53 & 2.44 & 0.09 \\
\hline Race: Asian & 3.10 & 2.93 & 0.17 \\
\hline \multicolumn{4}{|l|}{ Grade Point Average (English) } \\
\hline All Students & 3.01 & 2.69 & 0.32 \\
\hline Parental Education: High School Dropout & 2.74 & 2.49 & 0.25 \\
\hline Parental Education: Graduated High School & 2.87 & 2.53 & 0.34 \\
\hline Parental Education: Graduated College & 3.20 & 2.86 & 0.34 \\
\hline Race: White & 3.11 & 2.77 & 0.34 \\
\hline Race: Black & 2.71 & 2.37 & 0.34 \\
\hline Race: Hispanic & 2.80 & 2.53 & 0.27 \\
\hline Race: Asian & 3.30 & 2.97 & 0.33 \\
\hline \multicolumn{4}{|l|}{ Grade Point Average (Social Studies) } \\
\hline All Students & 3.00 & 2.79 & 0.21 \\
\hline Parental Education: High School Dropout & 2.73 & 2.59 & 0.14 \\
\hline Parental Education: Graduated High School & 2.86 & 2.62 & 0.24 \\
\hline Parental Education: Graduated College & 3.20 & 2.96 & 0.24 \\
\hline Race: White & 3.10 & 2.88 & 0.22 \\
\hline Race: Black & 2.68 & 2.43 & 0.25 \\
\hline Race: Hispanic & 2.78 & 2.60 & 0.18 \\
\hline Race: Asian & 3.28 & 3.05 & 0.23 \\
\hline
\end{tabular}


Table 2. Average Test Scores by Gender, School Lunch Eligibility and Race

Average Test Score (Math 4th Grade)

All Students

Eligible for National School Lunch Program

Not Eligible for National School Lunch Program

Race: White

Race: Black

Race: Hispanic

Race: Asian

Average Test Score (Math 8th Grade)

All Students

Eligible for National School Lunch Program

Not Eligible for National School Lunch Program

Race: White

Race: Black

Race: Hispanic

Race: Asian

Average Test Score (Science 8th Grade)

All Students

Eligible for National School Lunch Program

Not Eligible for National School Lunch Program

Race: White

Race: Black

Race: Hispanic

Race: Asian

Average Test Score (Reading 4th Grade)

All Students

Eligible for National School Lunch Program

Not Eligible for National School Lunch Program

Race: White

Race: Black

Race: Hispanic

Race: Asian

Average Test Score (Reading 8th Grade)

All Students

Eligible for National School Lunch Program

Not Eligible for National School Lunch Program

Race: White

Race: Black

Race: Hispanic

Race: Asian

Average Test Score (Writing 8th Grade)

All Students

Eligible for National School Lunch Program

Not Eligible for National School Lunch Program

Race: White

Race: Black

Race: Hispanic

Race: Asian

Average Test Score (Writing 12th Grade)

All Students

Eligible for National School Lunch Program

Not Eligible for National School Lunch Program

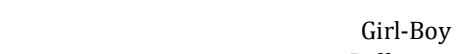

Girls Boys Difference

Race: White

Race: Black

Race: Hispanic

Race: Asian

Source: National Assessment of Educational Progress, 2011. 


\begin{tabular}{|lccc|}
\hline \multicolumn{3}{|l|}{ Table 3. Access to Personal Computers at Home by Boys and Girls } \\
\hline \hline \\
\cline { 2 - 4 } & & & \\
& Percent with access to a home computer \\
\cline { 2 - 4 } Total & Girls & Boys & $\begin{array}{c}\text { Girl-Boy } \\
\text { Difference }\end{array}$ \\
Girl only household & $84 \%$ & $84 \%$ & $0 \%$ \\
Boy only household & $85 \%$ & & \\
Girl and boy household & & $85 \%$ & \\
Ages 5-9 & $83 \%$ & $83 \%$ & $0 \%$ \\
Ages 10-14 & $81 \%$ & $82 \%$ & $0 \%$ \\
Ages 15-17 & $85 \%$ & $84 \%$ & $1 \%$ \\
Family income $<\$ 20,000$ & $86 \%$ & $87 \%$ & $0 \%$ \\
Family income $\$ 20,000-39,999$ & $62 \%$ & $60 \%$ & $2 \%$ \\
Family income \$40,000-74,999 & $75 \%$ & $75 \%$ & $-1 \%$ \\
Family income \$75,000-99,999 & $91 \%$ & $92 \%$ & $-1 \%$ \\
Family income \$100,000 or more & $97 \%$ & $96 \%$ & $1 \%$ \\
White, non-Hispanic & $98 \%$ & $97 \%$ & $1 \%$ \\
Hispanic & $91 \%$ & $91 \%$ & $1 \%$ \\
Black & $70 \%$ & $71 \%$ & $-1 \%$ \\
Asian & $75 \%$ & $75 \%$ & $0 \%$ \\
\hline Source: Current Population Survey, Computer and Internet Supplement 2011 Microdata. & $-3 \%$ \\
\hline
\end{tabular}




\begin{tabular}{|c|c|c|c|}
\hline & Girls & Boys & $\begin{array}{c}\text { Girl-Boy } \\
\text { Difference }\end{array}$ \\
\hline \multicolumn{4}{|l|}{ Current Population Survey 2003} \\
\hline Percent of Internet users using for playing games & $61 \%$ & $68 \%$ & $-7 \%$ \\
\hline Low-income children & $59 \%$ & $65 \%$ & $-6 \%$ \\
\hline High-income children & $63 \%$ & $69 \%$ & $-6 \%$ \\
\hline Percent of Internet users using for email and messaging & $64 \%$ & $57 \%$ & $7 \%$ \\
\hline Low-income children & $52 \%$ & $49 \%$ & $3 \%$ \\
\hline High-income children & $69 \%$ & $60 \%$ & $9 \%$ \\
\hline Percent of Internet users using for school assignments & $79 \%$ & $77 \%$ & $2 \%$ \\
\hline Low-income children & $75 \%$ & $73 \%$ & $2 \%$ \\
\hline High-income children & $80 \%$ & $78 \%$ & $2 \%$ \\
\hline Percent using Internet anywhere & $61 \%$ & $58 \%$ & $3 \%$ \\
\hline Low-income children & $49 \%$ & $46 \%$ & $3 \%$ \\
\hline High-income children & $70 \%$ & $69 \%$ & $1 \%$ \\
\hline \multicolumn{4}{|l|}{ Pew Internet Study (2007-08) } \\
\hline Percent playing video games daily & $22 \%$ & $39 \%$ & $-17 \%$ \\
\hline Low-income children & $23 \%$ & $40 \%$ & $-17 \%$ \\
\hline High-income children & $20 \%$ & $37 \%$ & $-17 \%$ \\
\hline Percent sending email on a daily basis & $20 \%$ & $12 \%$ & $8 \%$ \\
\hline Low-income children & $20 \%$ & $11 \%$ & $9 \%$ \\
\hline High-income children & $17 \%$ & $10 \%$ & $7 \%$ \\
\hline Percent using Internet ever for school research & $96 \%$ & $92 \%$ & $4 \%$ \\
\hline Low-income children & $89 \%$ & $88 \%$ & $1 \%$ \\
\hline High-income children & $97 \%$ & $92 \%$ & $5 \%$ \\
\hline \multicolumn{4}{|l|}{ Kaiser Foundation Time Use Diary 2009} \\
\hline Minutes of computer use for playing games & 8 & 25 & -17 \\
\hline Minutes of computer use for videos and other entertainme] & 19 & 23 & -4 \\
\hline Minutes of computer use for social networking & 25 & 19 & 6 \\
\hline Minutes of computer use for email and instant messaging & 18 & 16 & 2 \\
\hline Minutes of computer use for other activities & 12 & 14 & -2 \\
\hline Minutes of computer use for schoolwork & 19 & 13 & 6 \\
\hline Total minutes per day of computer use & 101 & 110 & -9 \\
\hline
\end{tabular}




\begin{tabular}{|c|c|c|c|c|c|}
\hline & \multirow{3}{*}{$\begin{array}{c}\text { (1) } \\
\text { How many } \\
\text { hours per week } \\
\text { do you spend } \\
\text { on homework? }\end{array}$} & \multirow{2}{*}{\multicolumn{3}{|c|}{$\begin{array}{l}\text { (2) } \quad(3) \\
\text { How often do you turn in homework on } \\
\text { time? }\end{array}$}} & \multirow{3}{*}{$\begin{array}{l}\text { (5) } \\
\text { How much time did } \\
\text { you spend on last } \\
\text { essay? }\end{array}$} \\
\hline & & & & & \\
\hline & & Always & Usually & Sometimes & \\
\hline \multirow[t]{2}{*}{ Girl treatment } & -0.38 & -0.01 & -0.02 & 0.03 & -0.22 \\
\hline & $(0.38)$ & $(0.05)$ & $(0.05)$ & $(0.04)$ & $(1.15)$ \\
\hline \multirow[t]{2}{*}{ Boy treatment } & 0.20 & -0.07 & 0.07 & 0.00 & 0.16 \\
\hline & $(0.39)$ & $(0.05)$ & $(0.05)$ & $(0.04)$ & (1.17) \\
\hline \multirow[t]{2}{*}{ Girl-boy treatment diff. } & -0.58 & 0.06 & -0.10 & 0.04 & -0.38 \\
\hline & $(0.56)$ & $(0.07)$ & $(0.07)$ & $(0.05)$ & $(1.66)$ \\
\hline Observations & 825 & 853 & 853 & 853 & 805 \\
\hline Girl control mean & 2.79 & 0.48 & 0.37 & 0.15 & 4.02 \\
\hline Boy control mean & 2.49 & 0.46 & 0.38 & 0.17 & 4.77 \\
\hline \multicolumn{6}{|c|}{$\begin{array}{l}\text { Notes: Data is from follow-up survey completed by students at end of school year. Regressions include controls } \\
\text { for sampling strata (school*year) and variables listed in Appendix Table } 1 .{ }^{* * *},{ }^{* *},{ }^{*} \text { indicates significance at } 1,5 \\
\text { and } 10 \% \text {. }\end{array}$} \\
\hline
\end{tabular}




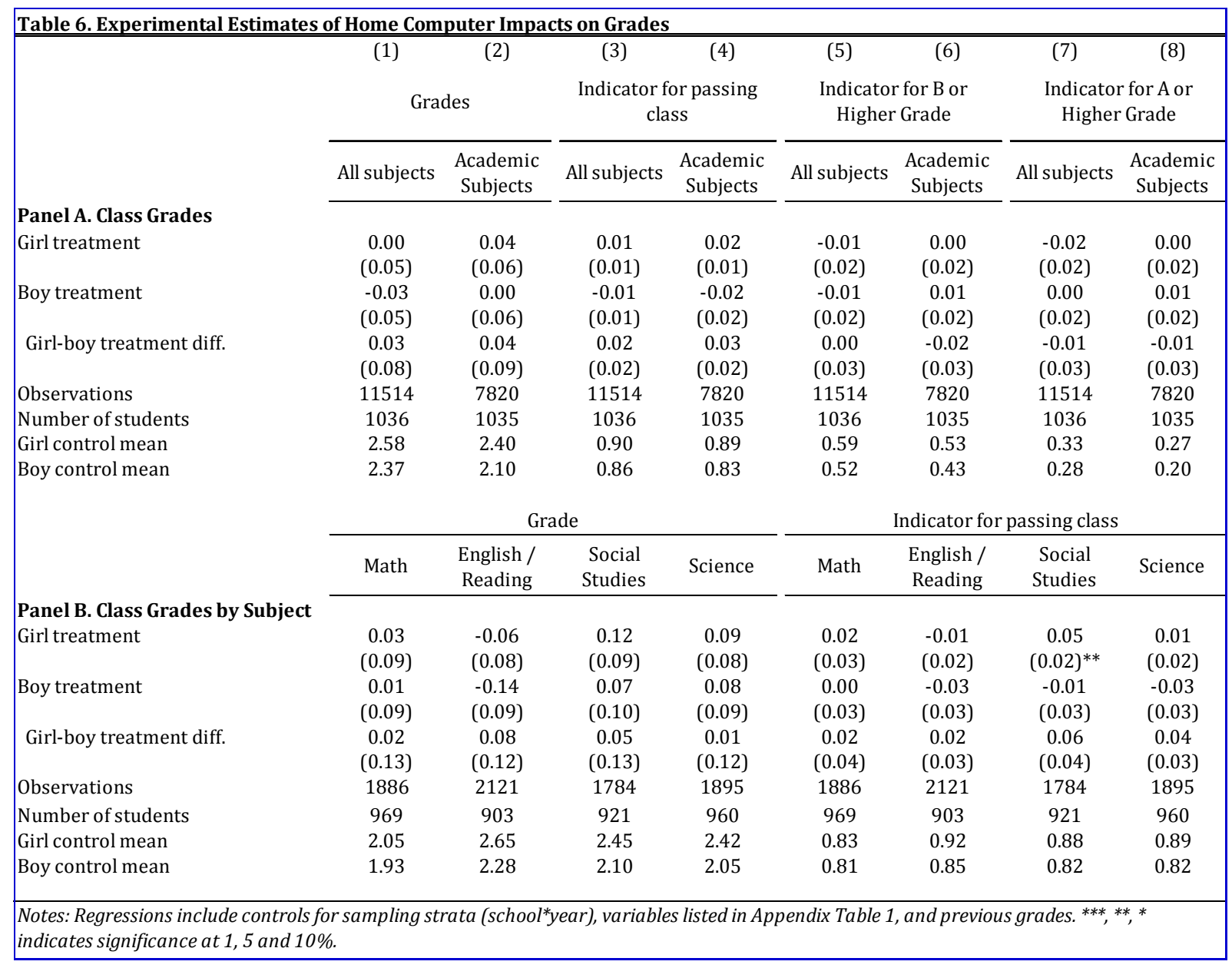




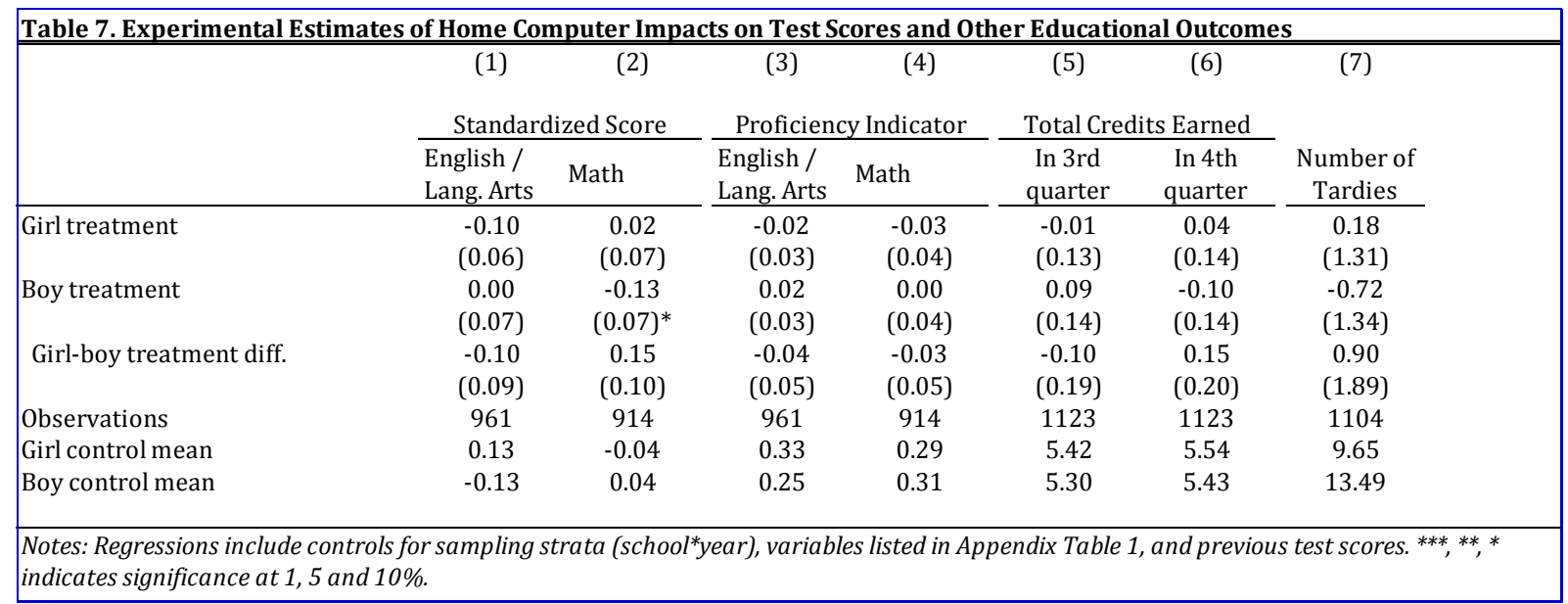




\begin{tabular}{|c|c|c|c|c|c|c|c|c|c|}
\hline & \multicolumn{3}{|c|}{ Total } & \multicolumn{3}{|c|}{ Girls } & \multicolumn{3}{|c|}{ Boys } \\
\hline & Control & Treatment & $\begin{array}{c}\text { Equality of } \\
\text { means } \\
p \text {-value }\end{array}$ & Control & Treatment & $\begin{array}{c}\text { Equality of } \\
\text { means } \\
\text {-value }\end{array}$ & Control & Treatment & $\begin{array}{c}\text { Equality of } \\
\text { means } \\
p \text {-value }\end{array}$ \\
\hline Age & $\begin{array}{l}12.91 \\
(0.87)\end{array}$ & $\begin{array}{l}12.90 \\
(0.84)\end{array}$ & 0.91 & $\begin{array}{l}12.92 \\
(0.91)\end{array}$ & $\begin{array}{l}12.85 \\
(0.78)\end{array}$ & 0.37 & $\begin{array}{l}12.90 \\
(0.83)\end{array}$ & $\begin{array}{l}12.96 \\
(0.89)\end{array}$ & 0.46 \\
\hline Female & $\begin{array}{c}0.51 \\
(0.50)\end{array}$ & $\begin{array}{c}0.50 \\
(0.50)\end{array}$ & 0.66 & 1 & 1 & & 0 & 0 & \\
\hline Ethnicity = African American & $\begin{array}{c}0.13 \\
(0.34)\end{array}$ & $\begin{array}{c}0.14 \\
(0.34)\end{array}$ & 0.86 & $\begin{array}{c}0.14 \\
(0.35)\end{array}$ & $\begin{array}{c}0.13 \\
(0.34)\end{array}$ & 0.66 & $\begin{array}{c}0.13 \\
(0.33)\end{array}$ & $\begin{array}{c}0.15 \\
(0.35)\end{array}$ & 0.50 \\
\hline Ethnicity = Latino & $\begin{array}{c}0.56 \\
(0.50)\end{array}$ & $\begin{array}{c}0.55 \\
(0.50)\end{array}$ & 0.76 & $\begin{array}{c}0.55 \\
(0.50)\end{array}$ & $\begin{array}{c}0.57 \\
(0.50)\end{array}$ & 0.66 & $\begin{array}{c}0.57 \\
(0.50)\end{array}$ & $\begin{array}{c}0.54 \\
(0.50)\end{array}$ & 0.38 \\
\hline Ethnicity = Asian & $\begin{array}{c}0.12 \\
(0.33)\end{array}$ & $\begin{array}{c}0.14 \\
(0.34)\end{array}$ & 0.42 & $\begin{array}{c}0.12 \\
(0.33)\end{array}$ & $\begin{array}{c}0.14 \\
(0.35)\end{array}$ & 0.49 & $\begin{array}{c}0.12 \\
(0.33)\end{array}$ & $\begin{array}{c}0.13 \\
(0.34)\end{array}$ & 0.66 \\
\hline Ethnicity $=$ White $^{1}$ & $\begin{array}{c}0.16 \\
(0.36)\end{array}$ & $\begin{array}{c}0.14 \\
(0.35)\end{array}$ & 0.56 & $\begin{array}{c}0.16 \\
(0.37)\end{array}$ & $\begin{array}{c}0.14 \\
(0.35)\end{array}$ & 0.61 & $\begin{array}{c}0.15 \\
(0.36)\end{array}$ & $\begin{array}{c}0.15 \\
(0.35)\end{array}$ & 0.76 \\
\hline Immigrant & $\begin{array}{c}0.21 \\
(0.41)\end{array}$ & $\begin{array}{c}0.18 \\
(0.38)\end{array}$ & 0.15 & $\begin{array}{c}0.21 \\
(0.41)\end{array}$ & $\begin{array}{c}0.18 \\
(0.39)\end{array}$ & 0.40 & $\begin{array}{c}0.21 \\
(0.41)\end{array}$ & $\begin{array}{c}0.17 \\
(0.38)\end{array}$ & 0.23 \\
\hline Primary language is English & $\begin{array}{c}0.43 \\
(0.50)\end{array}$ & $\begin{array}{c}0.43 \\
(0.50)\end{array}$ & 0.97 & $\begin{array}{c}0.43 \\
(0.50)\end{array}$ & $\begin{array}{c}0.43 \\
(0.50)\end{array}$ & 0.98 & $\begin{array}{c}0.43 \\
(0.50)\end{array}$ & $\begin{array}{c}0.43 \\
(0.50)\end{array}$ & 0.97 \\
\hline Parent's education $^{2}$ & $\begin{array}{l}12.81 \\
(1.44)\end{array}$ & $\begin{array}{l}12.76 \\
(1.49)\end{array}$ & 0.64 & $\begin{array}{l}12.71 \\
(1.48)\end{array}$ & $\begin{array}{l}12.77 \\
(1.50)\end{array}$ & 0.67 & $\begin{array}{l}12.94 \\
(1.39)\end{array}$ & $\begin{array}{l}12.75 \\
(1.48)\end{array}$ & 0.22 \\
\hline Number of people living in household & $\begin{array}{c}4.98 \\
(2.43)\end{array}$ & $\begin{array}{c}5.02 \\
(2.55)\end{array}$ & 0.79 & $\begin{array}{c}5.03 \\
(2.34)\end{array}$ & $\begin{array}{c}5.13 \\
(2.47)\end{array}$ & 0.62 & $\begin{array}{c}4.93 \\
(2.53)\end{array}$ & $\begin{array}{c}4.92 \\
(2.63)\end{array}$ & 0.95 \\
\hline Lives with mother & $\begin{array}{c}0.92 \\
(0.28)\end{array}$ & $\begin{array}{c}0.89 \\
(0.32)\end{array}$ & 0.12 & $\begin{array}{c}0.90 \\
(0.30)\end{array}$ & $\begin{array}{c}0.91 \\
(0.29)\end{array}$ & 0.77 & $\begin{array}{c}0.93 \\
(0.25)\end{array}$ & $\begin{array}{c}0.87 \\
(0.34)\end{array}$ & $0.014^{* *}$ \\
\hline Lives with father & $\begin{array}{c}0.58 \\
(0.49)\end{array}$ & $\begin{array}{c}0.58 \\
(0.49)\end{array}$ & 0.90 & $\begin{array}{c}0.53 \\
(0.50)\end{array}$ & $\begin{array}{c}0.56 \\
(0.50)\end{array}$ & 0.48 & $\begin{array}{c}0.64 \\
(0.48)\end{array}$ & $\begin{array}{c}0.60 \\
(0.49)\end{array}$ & 0.33 \\
\hline Does your mother have job? ${ }^{4}$ & $\begin{array}{c}0.47 \\
(0.50)\end{array}$ & $\begin{array}{c}0.46 \\
(0.50)\end{array}$ & 0.68 & $\begin{array}{c}0.47 \\
(0.50)\end{array}$ & $\begin{array}{c}0.44 \\
(0.50)\end{array}$ & 0.55 & $\begin{array}{c}0.47 \\
(0.50)\end{array}$ & $\begin{array}{c}0.48 \\
(0.50)\end{array}$ & 0.98 \\
\hline Does your father have a job? & $\begin{array}{c}0.73 \\
(0.44)\end{array}$ & $\begin{array}{c}0.70 \\
(0.46)\end{array}$ & 0.36 & $\begin{array}{c}0.70 \\
(0.46)\end{array}$ & $\begin{array}{c}0.65 \\
(0.48)\end{array}$ & 0.41 & $\begin{array}{c}0.77 \\
(0.43)\end{array}$ & $\begin{array}{c}0.74 \\
(0.44)\end{array}$ & 0.66 \\
\hline Full sample size & 564 & 559 & & 289 & 279 & & 275 & 280 & \\
\hline $\begin{array}{l}\text { Notes: In Columns } 1,2,4,5,7 \text { and } 8, \text { me } \\
\text { equality of means. ***, **, * indicates si } \\
1 \text { Omitted ethnicity category is "not rep } \\
2 \text { This is the highest education level of e } \\
3 \text { The variables for mother's and father }\end{array}$ & $\begin{array}{l}\text { ins report } \\
\text { nificance } \\
\text { rted." } \\
\text { ther paren } \\
\text { job is rep }\end{array}$ & $\begin{array}{l}\text { with stand } \\
\text { t1, } 5 \text { and } 10 \\
\text { (which is th } \\
\text { rted only for }\end{array}$ & $\begin{array}{l}\text { lard errors in } \\
0 \% \text {. } \\
\text { e measure } m\end{array}$ & arenthes & Column 3 , & 6 and 9 repo & the $p-v$ & efor the & st for the \\
\hline
\end{tabular}




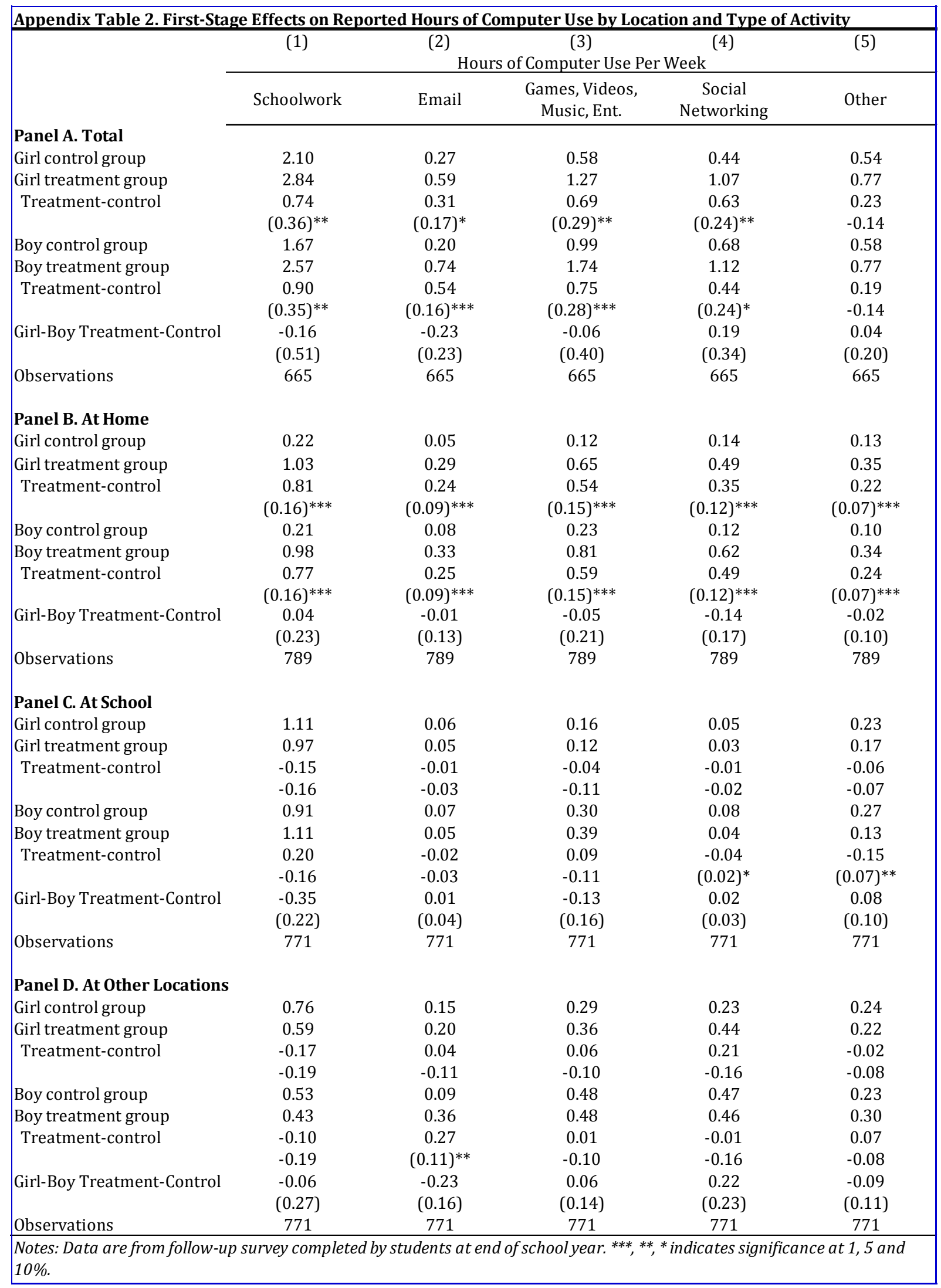




\begin{tabular}{|c|c|c|c|}
\hline & Girls & Boys & $\begin{array}{c}\text { Girl-Boy } \\
\text { Difference }\end{array}$ \\
\hline Percent of 5-year olds enrolled in primary school (CPS 2011) & $76.5 \%$ & $73.4 \%$ & $3.0 \%$ \\
\hline \multicolumn{4}{|l|}{ Early-age test scores } \\
\hline First-time kindergartners' mean reading scale score (ECLS-K 2011) & 50.5 & 48.5 & 2.0 \\
\hline First-time kindergartners' mean mathematics scale score (ECLS-K 2011) & 42.0 & 42.0 & 0.0 \\
\hline Average early reading scale score - children less than 48 months (ECLS-B 2007) & 22.4 & 20.7 & 1.7 \\
\hline Average early reading scale score - children 48-57 months (ECLS-B 2007) & 26.4 & 24.6 & 1.8 \\
\hline Average early reading scale score - children over 58 months (ECLS-B 2007) & 30.4 & 29.0 & 1.4 \\
\hline Grade retention: 9th grade students ever retained (K-9) (HSLS 2009) & $10.0 \%$ & $15.0 \%$ & $-5.0 \%$ \\
\hline \multicolumn{4}{|l|}{ Learning difficulties } \\
\hline Diagnosed with a learning disability (NHIS 2008) & $7.3 \%$ & $11.4 \%$ & $-4.1 \%$ \\
\hline Diagnosed with Attention Deficit Hyperactivity Disorder (NHIS 2008) & $5.3 \%$ & $16.6 \%$ & $-11.3 \%$ \\
\hline Percentage of gifted and talented students (CRDC 2006) & $7.0 \%$ & $6.3 \%$ & $0.7 \%$ \\
\hline \multicolumn{4}{|l|}{ Truancy and disciplinary } \\
\hline Students aged 12-18 who skipped any classes in previous 4 weeks (SCS 2007) & $4.7 \%$ & $6.2 \%$ & $-1.5 \%$ \\
\hline Public school students in 9th-12th grade who had ever been suspended (SCS 2007) & $16.9 \%$ & $31.7 \%$ & $-14.8 \%$ \\
\hline Public school students in 9th-12th grade who had ever been expelled (SCS 2007) & $1.9 \%$ & $4.4 \%$ & $-2.5 \%$ \\
\hline \multicolumn{4}{|l|}{ Advanced placement and activities } \\
\hline Advanced placement examination participation (CBNSR 2009-10) & $56.0 \%$ & $44.0 \%$ & $12.0 \%$ \\
\hline Average credits earned - advanced placement courses, grade 12 (CBNSR 2009-10) & 1.20 & 0.96 & 0.24 \\
\hline High school seniors who participated in student council/government (MTF 2009) & $13.1 \%$ & $5.9 \%$ & $7.2 \%$ \\
\hline Average freshman graduation rate (CCD 2008-09) & $79.0 \%$ & $72.0 \%$ & $7.0 \%$ \\
\hline Percent of population aged 18-24 without a high school degree (CPS 2012) & $17.2 \%$ & $20.3 \%$ & $3.1 \%$ \\
\hline \multicolumn{4}{|c|}{$\begin{array}{l}\text { Sources: National Center for Education Statistics, Early Childhood Longitudinal Study, Kindergarten Class of 2010-11 } \\
\text { (ECLS-K:2011); National Center for Health Statistics, National Health Interview Survey (NHIS 2008); Current Population } \\
\text { Survey (CPS 2012); National Center for Education Statistics, Common Core of Data (CCD 2008-09); National Center for } \\
\text { Education Statistics, Early Childhood Longitudinal Study, Birth Cohort (ECLS-B 2007); U.S. Department of Education, Office } \\
\text { for Civil Rights, Civil Rights Data Collection (CRDC 2006); University of Michigan, Institute for Social Research, Monitoring } \\
\text { the Future, (MTF 2009); The College Board, AP Program National Summary Reports (CBNSR 2009-10); U.S. Department of } \\
\text { Justice, Bureau of Justice Statistics, School Crime Supplement (SCS) to the National Crime Victimization Survey (NCVS) (SCS } \\
\text { 2007). }\end{array}$} \\
\hline
\end{tabular}

